\title{
Responsibility in Health Care
}

\author{
Mareli M. Claassens
}

Thesis presented in partial fulfilment of the requirements for the degree

Master of Philosophy (Applied Ethics)

at

Stellenbosch University

Supervisor: Professor Anton A. van Niekerk

March 2010 


\section{Declaration}

By submitting this thesis electronically, I declare that the entirety of the work contained therein is my own, original work, that I am the owner of the copyright thereof (unless to the extent explicitly otherwise stated) and that I have not previously in its entirety or in part submitted it for obtaining any qualification.

Date: 22 January 2010

Copyright (C) 2009 Stellenbosch University

All rights reserved 


\begin{abstract}
This thesis deals with issues surrounding responsibility in health care, especially with regards to responsibility in the South African context against the background of the HIV/AIDS epidemic. It aims to unpack different concepts of responsibility and the application of these concepts within the framework of a health care system. Firstly, a historical perspective of the idea of individual moral responsibility is discussed. It is argued that for all practical reasons, an individual should and must be held responsible for his choices and actions, considering the fact that ultimate moral responsibility from a deterministic point of view may not exist. Secondly, medical responsibility from an individual and a collective point of view is investigated. A brief historical overview is given about the development of the concept of collective moral responsibility. The complex moral-medical ethical dilemmas a medical professional faces because of internal conflict secondary to plural responsibilities, are discussed. Thirdly, an ethics of responsibility, and how a medical professional could choose to abide by such an ethics as part of her own moral values and belief system, is investigated. Then, the preceding theoretical knowledge is applied to a real life situation in a case study dealing with people living with HIV/AIDS in South Africa.

The ultimate goal of the thesis is to highlight different types of responsibility in health care, to discuss the responsibilities of different role players in health care, and to ultimately argue that the ascription and acceptance of responsibility is an extremely important necessity if people living with HIV/AIDS in South Africa are to be treated fairly, effectively and without delay.
\end{abstract}




\section{Opsomming}

Hierdie tesis bespreek kwessies aangaande verantwoordelikheid in gesondheidsorg, spesifiek met betrekking tot verantwoordelikheid in die Suid-Afrikaanse konteks waar 'n HIV/VIGS epidemie tans heers. Die skrywer beoog om verskillende konsepte van verantwoordelikheid te verduidelik en dan hierdie konsepte toe te pas binne die raamwerk van 'n gesondheidsorgsisteem. 'n Historiese perspektief van individuele morele verantwoordelikheid word eerstens bespreek. Daar word geargumenteer dat vir praktiese doeleindes enige individu verantwoordelik gehou moet word vir sy keuses en dade, nieteenstaande die feit dat ware morele verantwoordelikheid waarskynlik nie bestaan wanneer determinisme in ag geneem word nie. Tweedens word mediese verantwoordelikheid vanuit ' $n$ individuele en kollektiewe perspektief bespreek. 'n Historiese oorsig oor die ontwikkeling van die konsep van kollektiewe verantwoordelikheid word gegee. Daarna word komplekse moreel-mediese en etiese dilemmas wat enige mediese professionele persoon mee te doen mag kry as gevolg van verantwoordelikhede teenoor verskillende, en partykeer teenstrydige rolspelers, ondersoek. 'n Etiek van verantwoordelikheid word derdens bespreek. Riglyne word gegee oor hoe 'n mediese professionele persoon haarself aan so 'n etiek kan onderwerp as deel van haar eie moraliteit en waarde sisteem. Laastens word alle voorafgaande teoretiese kennis van toepassing gemaak op 'n gevallestudie wat handel oor mense wat in Suid-Afrika met HIV/VIGS saamleef.

Die doelwit van die tesis is om verskillende tipes verantwoordelikheid in ' $\mathrm{n}$ gesondheidsorgsisteem te ondersoek, om die verantwoordelikheid wat verskillende rolspelers in so 'n sisteem dra, te bespreek, en om te betoog dat die aanvaarding van verantwoordelikheid op verskillende platforms in die Suid-Afrikaanse gesondheidsorgsisteem essensieël is om te verseker dat mense wat met HIV/VIGS saamleef, regverdig, effektief en sonder uitstel behandel word. 


\section{Table of contents}

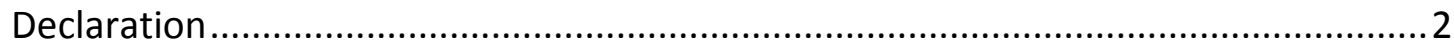

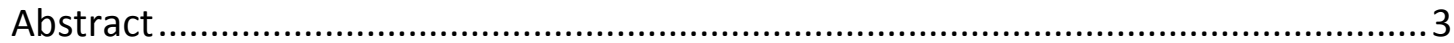

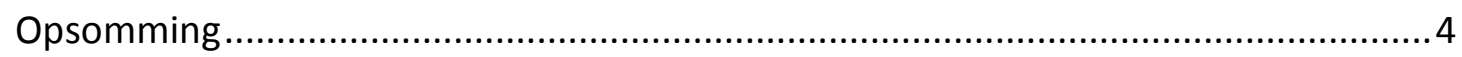

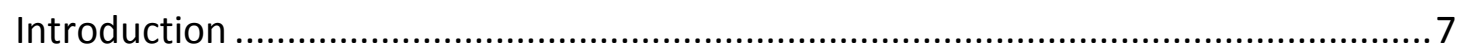

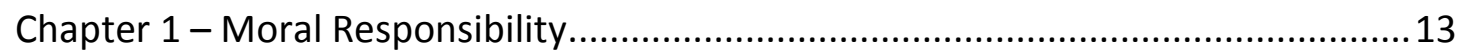

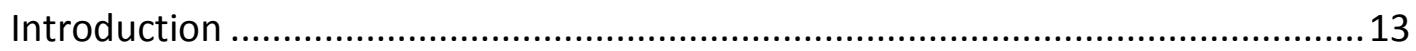

The first theory of moral responsibility ........................................................ 17

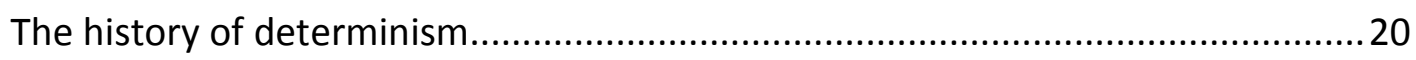

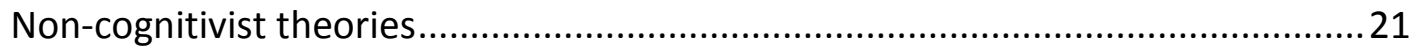

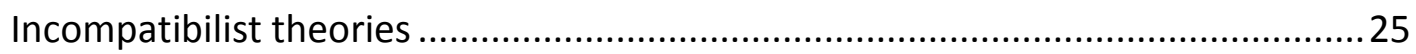

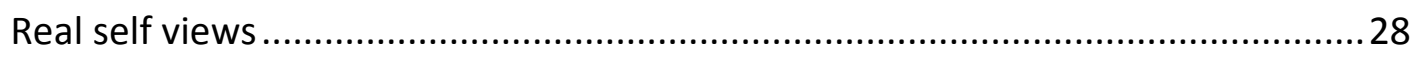

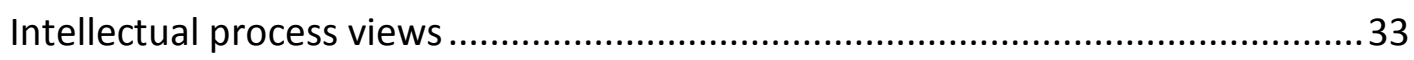

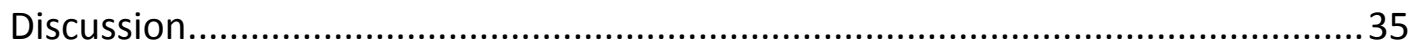

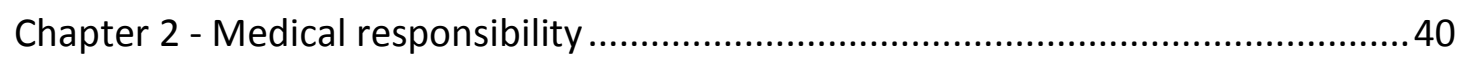

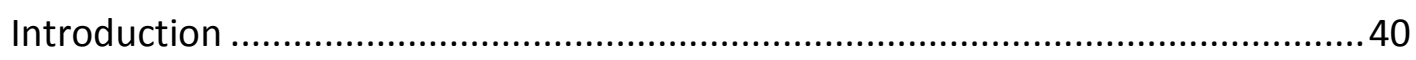

Questions about responsibility in healthcare .................................................. 42

How is moral agency and responsibility allocated? ............................................ 44

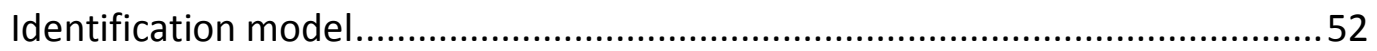

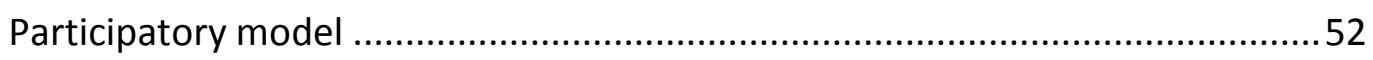

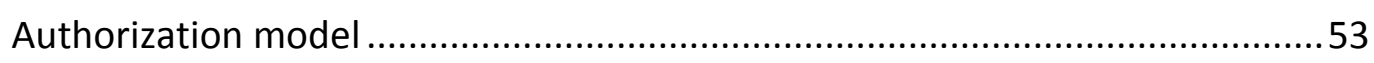

How is each member's moral agency influenced by the collective?.......................55

To whom is moral responsibility primarily due? ................................................58

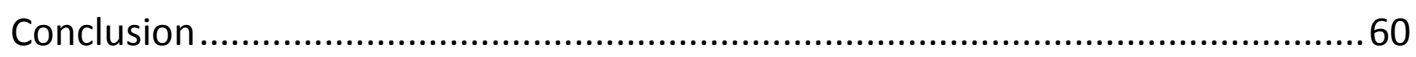




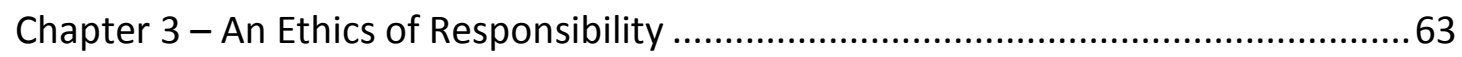

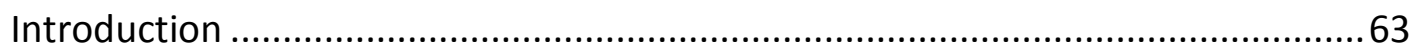

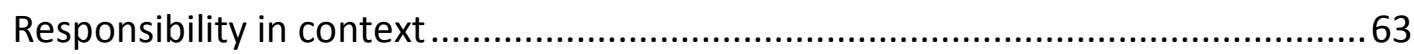

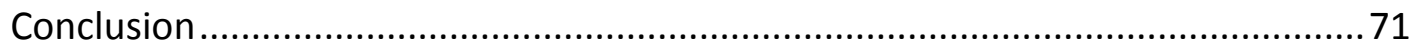

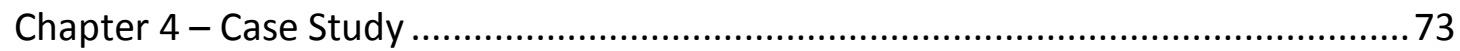

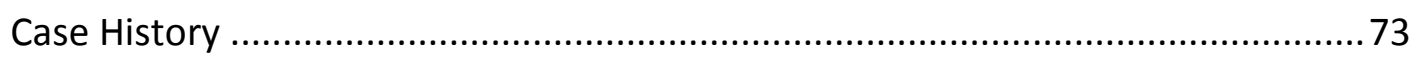

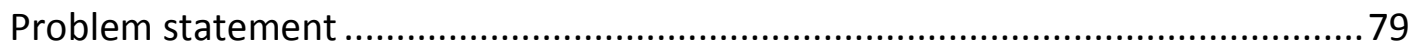

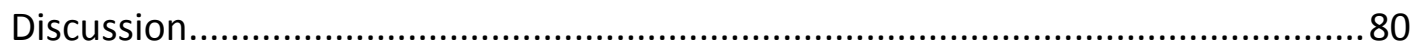

How is this case then relevant to the discussion on responsibility? .......................82

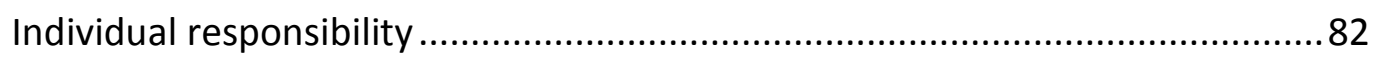

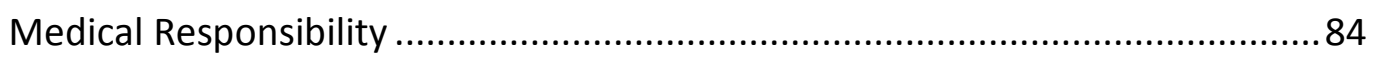

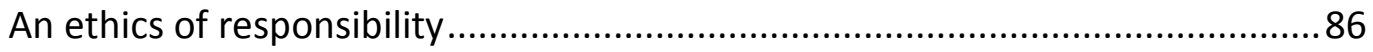

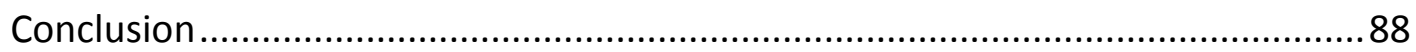

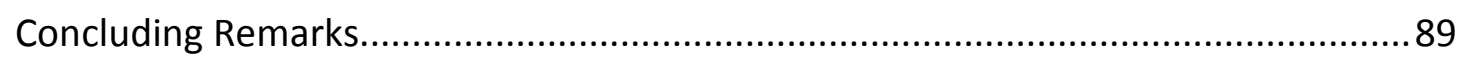

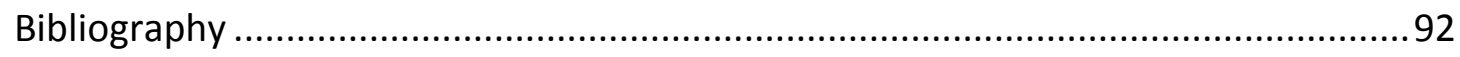




\section{Introduction}

The goal of this thesis is primarily to discuss questions about the notion and practice of responsibility in the health care setting against the background of an HIV/AIDS epidemic in South Africa where the first cases were identified in 1982 and the incidence and prevalence is still increasing. The term responsibility can be interpreted in different ways, of which the etymology "answerable (to another, for something)," from French responsible, from Latin responsus and the meaning "morally accountable for one's actions" is attested from $1836 .{ }^{1}$ However, when answering the question: "What does responsibility in health care entail?", the etymology and meaning of the word in its purest sense are not the only aspects needing investigation and explanation. This thesis explores different meanings of responsibility in the health care setting, starting with individual responsibility in the first chapter where a historical overview of the concept is given. The next chapter deals with medical responsibility in an individual and collective sense, whereas the third chapter focuses on an ethics of responsibility. These three meanings of responsibility are then illuminated by the case study in the fourth chapter, where the author applies the different concepts to a real life scenario. The case study highlights the plight of medical professionals dealing with HIV/AIDS in South Africa, where the proper assignment of responsibility is of cardinal importance to ensure good quality of care to people living with HIV/AIDS.

The first Human Immunodeficiency Virus (HIV) cases were identified in South Africa in 1982 (Whiteside \& Sunter, 2000). The virus mainly affected homosexuals in the first eight years, but then started to spread amongst other groups. In July 1991 the number of heterosexual cases equalled the number of homosexual cases. Since then the heterosexual epidemic has totally overshadowed the homosexual case load. The collection and publication of AIDS case data stopped in 1995 when AIDS ceased to be a notifiable disease. Annual antenatal surveys carried out since 1994 across South

\footnotetext{
${ }^{1}$ www.etymonline.com
} 
Africa delivered the data needed for calculation of overall prevalence of disease. The HIV prevalence steadily rose from 0.8 per cent in 1990 to 22.4 per cent in 1999.

Because of the spread of the infection, South Africa now faces a major AIDS epidemic. Anti-retroviral therapy (ART) was officially instated only in 2004, and rollout has been slow and tedious. Even in 2008 not all people infected with HIV had access to therapy. We are still concerned with HIV/AIDS because it causes people to become ill and die. The people affected by HIV/AIDS are mostly vulnerable, poor and uneducated with poor access to health care. The AIDS victims also include children, for whom a working ART-program was even slower to be established.

The health care of these vulnerable groups is dependent on the Department of Health and its employees. The primary goal of such a department should unequivocally be the improvement and promotion of health and well-being of patients. Focusing specifically on the HIV/AIDS epidemic, this goal would include promoting the health and well-being of people living with HIV/AIDS. When the author recently worked in the Transkei, she met a five year old child who was HIVpositive and critically ill. The child was dying simply because anti-retrovirals were not available in the public health sector at the time, and the social circumstances of the child's family made it impossible for them to afford private health care and pharmaceuticals. This situation raised the question of who is to take responsibility for the well-being of this child? His mother, who gave him the infection but is too poor, uneducated and stigmatised herself to change his circumstances? The doctor looking after him, who works in conditions not of her own making, not having made the decision that anti-retrovirals should not be available? The hospital, endorsing the policies prescribed by the department of health? Or the Department of Health, being the ultimate decision-maker?

This thesis therefore deals with the question of responsibility in the health care setting in South Africa. By elaborating on different aspects or meanings of responsibility, the author tries to answer the following questions: "Can any individual have ultimate moral responsibility? What is a medical professional's individual or collective responsibility? What is an ethics of responsibility with 
regards to the health care setting?" These questions are discussed on a philosophical basis, but then elaborated upon while taking the high HIV/AIDS prevalence in South Africa into account, and the day-to-day application of such concepts of responsibility when a complex bio-psycho-social disease such as HIV/AIDS is encountered.

In chapter 1, the history of moral responsibility is discussed. The first moral responsibility theory by Aristotle in his Nicomachean Ethics is the backbone of the discussion. He focuses on the intellectual virtues and so-called pro-airesis, which is defined as deliberate choice, as a concept for being a moral agent. The debate surrounding determinism is dealt with thereafter, comparing compatabilist and incompatabilist views by using prominent writers' theories. Peter Strawson's reactive attitudes and his son Galen Strawson's idea that ultimate moral responsibility is non-sensical, are discussed amongst others.

Chapter 2 deals with medical responsibility, from an individual and a collective's perspective. The assumption is made that an individual can indeed be morally responsible. It is then applied to the collective realm where a group of people all individually responsible, becomes responsible for the action of a collective. Questions surrounding the application of such a responsibility in the health care setting are addressed. Could a hospital, a medical board or an emergency team for instance be held collectively responsible? What about a medical association, or the medical profession? Every situation is analysed on its own terms before decisions about the assignment of collective medical responsibility are made.

In chapter 3 an ethics of responsibility is investigated. Opinions of Jonas, Levinas, and Van Niekerk are used to build the understanding of this ethical theory. The proposed method of prudent deliberation, informed choice and action with regards to consequences, whether planned or not, is discussed. Moral blame in the sense of an ethics of responsibility, entailing the acceptance of responsibility even when mistakes are made, forms part of the discussion.

Chapter 4 deals with the case study of dr Thys von Mollendorff, a physician from Nelspruit who allowed rape victims to be treated by an organisation called GRIP, and 
was subsequently relieved of his post as superintendent of the Rob Ferreira Hospital. The previous chapters are brought into discussion again, focusing on Von Mollendorff's responsibility as an individual, his responsibility as a medical professional and part of numerous collectives in the medical world, and his proposed acceptance of an ethics of responsibility.

Hopefully the discussion would contribute to the assumption and assignment of responsibility to all parties involved in this epidemic of HIV/AIDS in South Africa and to better health and well-being for its victims. It is however important to realise that the different concepts of responsibility each contribute to the question of who is responsible for health care in South Africa, and with regards to this thesis, who is responsible for caring for people living with HIV/AIDS in South Africa. The concept of an individual's moral responsibility per se is directly of consequence when responsibility needs to be ascribed to any individual living in South Africa and dealing on a daily basis with HIV/AIDS, whether it is as a patient, a medical professional, a government official, or any bystander witnessing the advance of the disease. The discussion hopes to illuminate the fact that all individuals in South Africa are morally responsible and therefore their choices and actions should be attributable to them as individuals.

Secondly, all medical professionals in South Africa are responsible as individuals, and their choices and actions are therefore attributable to them. They are however, not only responsible as pure individuals, but also as professionals. As professionals, they have further duties and obligations which conform to the role of the professional, and which they are obliged to adhere to. These duties include a certain way of decision-making and a certain way of action, which is not part of the responsibility ascribed to the man in the street. Medical professionals are responsible in their individual capacity, but as the thesis would like to show, they are also responsible as part of many collectives, or groups of individuals, for instance as part of a hospital staff or an emergency room team. The ascription of collective or group responsibility is therefore also part of this discussion, exploring the way in which responsibility could be ascribed when dealing with medical professionals who form part of different groups or collectives. 
Thirdly, a medical professional or any individual for that matter could choose to adhere to an ethics of responsibility. If a person would decide to adhere to such an ethics, it would mean that such an individual would at all times take into account not only his choices made and actions taken, but also the consequences of his actions ad infinitum, or at least the ones he would realistically know of. This thesis about responsibility in health care also incorporates a chapter on the ethics of responsibility, because any individual, or medical professional working with people living with HIV/AIDS in South Africa, could make the choice of adhering to an ethics of responsibility. This ethics of responsibility therefore is the third concept of responsibility which is discussed in depth. All three concepts of responsibility are then further highlighted by means of a case discussion as the fourth chapter.

The aim of the thesis would be to illuminate different concepts of responsibility in the health care setting, with specific regards to people living with HIV/AIDS in South Africa. The author discusses three different concepts of responsibility, keeping in mind that still other concepts may exist, but focusing on these because of their direct importance to the health care setting and medical professionalism in South Africa. 
A man can surely do what he wants to do. But he cannot determine what he wants.

Schopenhauer 


\section{Chapter 1 - Moral Responsibility}

\section{Introduction}

Can a person be held accountable for her deeds? Is an individual responsible for her thoughts and deliberations? Can someone accept responsibility for her actions? These questions are addressed in this chapter when the historical background of the concept of responsibility is investigated with specific regards to the determinism versus freedom debate. The question whether we could be held responsible for our actions or whether our actions are indeed predetermined by circumstances out of our control is addressed. This discussion links up to the central theme by focusing on the theoretical and philosophical issues surrounding responsibility in an individual, which is of importance when any such individual deliberates, chooses and acts. These issues will subsequently be discussed in a case study, where an individual has to deliberate, choose and act in the medical world.

The nature of the concept of responsibility is a philosophical conundrum because of the dissociation between freedom of the individual and determinism. It is argued that a cardinal condition of being a person means to be susceptible to moral praise and/or blame and therefore to be morally responsible (Eshleman 2004), but the conditions under which someone is to be morally responsible are impossible to fulfill if such a person is not free. According to determinism a person is not free to choose, and this distinction between the freedom to choose, and in this sense being free, and not to choose, i.e. not being free, is the root of the compatibilism/incompatibilism debate and defined as follows (Shafer-Landau, 2007:337):

“...everything that occurs does so as a result of a set of causes that, taken together, necessitate the outcome. Everything that happens therefore can be explained by a set of causes; nothing happens at random."

If a certain choice leads to an action, and this choice happens by chance, it is irrational to ascribe moral responsibility for the action. If however, the choice happens not by chance but is determined, responsibility could not be ascribed 
either. For the moralist, freedom of choice is the important element when distinguishing between compatibilism and incompatibilism. The type of choice an individual makes, depends on his character. But again, if his character is specified only by chance, responsibility ascription is irrational. Similarly, responsibility could not be ascribed if his character is determined. So to retain a concept of moral responsibility, an agent must either be responsible for actions not caused by free will, or another way of reconciling determinism with free will must be found.

In this chapter the discussion starts with Aristotle as the first philosopher to construct a theory of moral responsibility. His theory is based on voluntary action and deliberate choice. He is of the opinion that we can always choose virtue or vice, depending on ourselves. Kant in contrast thinks the qualities of temperament are irrelevant to moral judgment. He believes the only object of moral assessment is the determination of the will by the motive of duty.

Then follows a brief history of the development of the concept of moral responsibility, using a framework developed by Elizabeth Mason (2005) to simplify the discussion. The taxonomy of the theories about moral responsibility is shown in Figure 1. Mason divides philosophers into two camps with compatibilists on the one hand and incompatabilists on the other. Determinism is supported by the compatabilist theories, while the incompatibilists feel that moral responsibility could not be ascribed if determinism were true. Mason further divides the compatibilists into cognitivists and non-cognitivists to distinguish between different schools of thought with regards to the theory of compatabilism. It is however important to realise that many of the theories overlap and the distinction between categories is not always easy since the theories are part of a spectrum of discussion rather than a definitive and straight line of progress from one argument to the next.

The non-cognitivist position, characterised by the expression of attitudes (Mason 2005), is discussed by way of the theories of Peter Strawson, Jay Wallace and Thomas Nagel. Strawson introduces the concept of reactive attitudes, Wallace broadens (and complicates) the concept with cognitive elements, and Nagel uses 
Kant's theory to expand the concept of moral luck. He feels that agency as well as internal attitudes is of cardinal importance for a functional theory.

The cognitivist position, elaborating on the view that when we assign moral responsibility, we make a cognitive judgment that certain conditions obtain (Mason 2005), is firstly described by Galen Strawson, who uses Nietzsche's causa sui clause to formulate his basic argument. Richard Taylor then introduces the condition of agency which makes moral responsibility compatible with determinism if agency could be found intelligible. Frankfurt's theory of alternative possibilities and his hierarchical real self views are then discussed, followed by Susan Wolf's nonhierarchical deep self views. She introduces the condition of sanity instead of the causa sui clause which is, according to her, illogical in moral responsibility theory. Ayer then asks the question whether all actions really do indeed have to have a cause, and the scientific link to responsibility is further explored by Fischer. Hillary Bok ends the discussion on moral responsibility by focusing the attention on the practical applications and the fact that all individuals act as if many choices were available, even if on a metaphysical level ultimate moral responsibility is not attainable. 


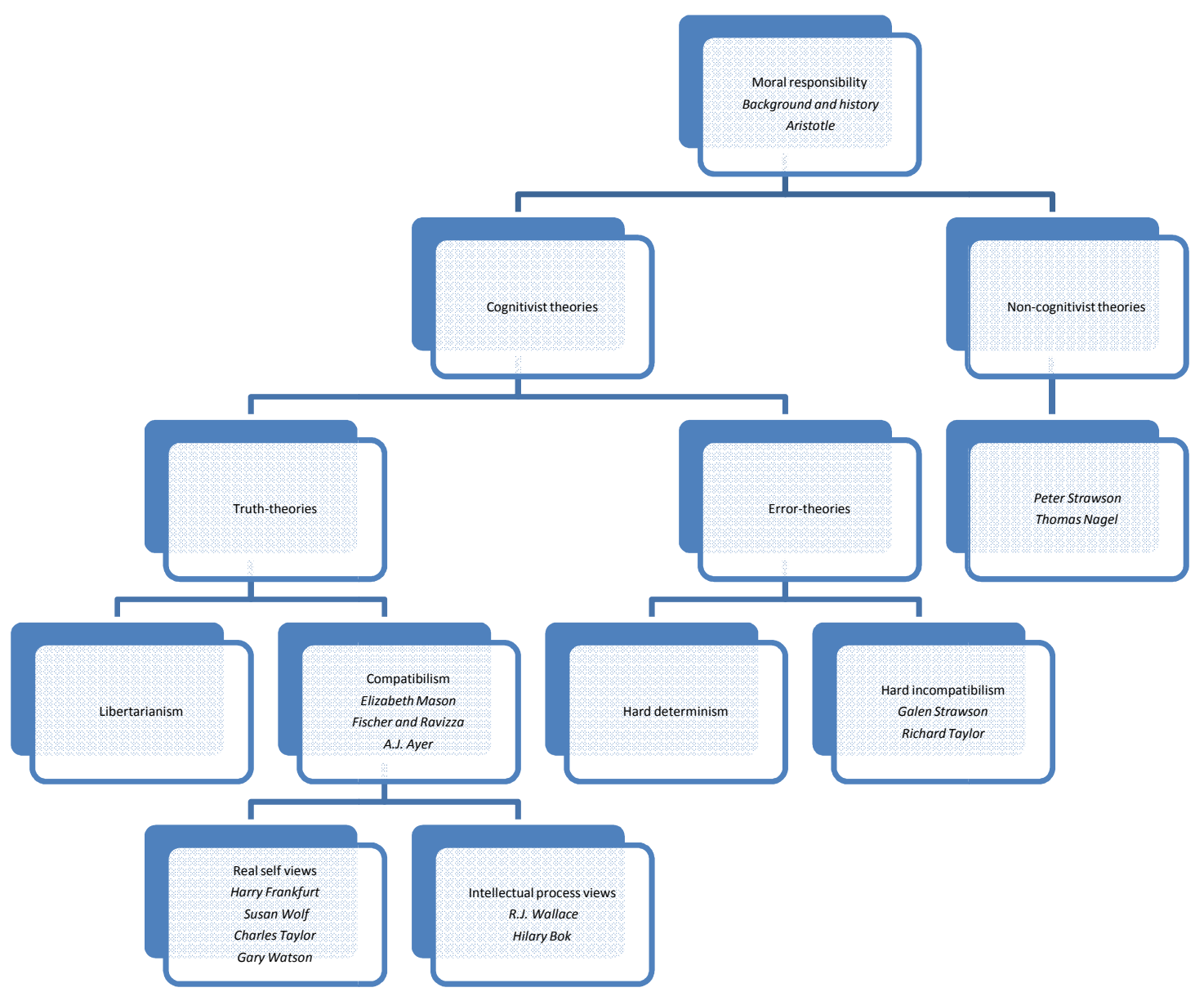

Figure 1: Taxonomy of the Theories about Moral Responsibility 


\section{The first theory of moral responsibility}

Historically the concept of moral responsibility was found in early Homeric texts (Mason, 2005). In these texts, a human or superhuman (god) would be praised or blamed according to the judgment of such an individual's actions by other humans or superhumans. The context of praise or blame was dependent on specific influencing factors, factors that influenced the agent's control over her actions. When an agent did not have any control over her actions, she could not be praised or blamed for her actions. The Greeks tended to be fatalists believing that all actions were predetermined, and therefore no human could be responsible for the outcome of an action. Human actions were believed to be otiose.

Aristotle, in his Nicomachean Ethics (1955), was the first person to construct a formal theory of moral responsibility. He argued against fatalism and the basis for his theory was formulated on the ability of a person to act voluntarily. His framework for a moral responsibility theory was constituted by four pillars, namely:

1. the concept of moral responsibility

2. the criteria for being a moral agent

3. the conditions under which the concept is applied

4. the objects of responsibility ascriptions

According to Aristotle a voluntary action is an action where the origin or cause lies within the agent and the agent is aware of the particular circumstances surrounding the action. Only to voluntary action can praise or blame be assigned. Involuntary action is defined as an action either performed under compulsion, i.e. caused by something external to the agent with no contribution whatsoever from the agent, or as a result of ignorance. This ignorance is not defined as a general ignorance, but as an ignorance with specific regard to the circumstances surrounding the particular action. Any action could be voluntary or involuntary judging by the particular circumstances, but the classification of such an action would be according to the objective (or end) of the action at the time of the action. An ignorant action could only be so when the agent felt subsequent regret; if not, such an action would be regarded as 'non-voluntary'. 
A clear distinction has to be made between an action completed as a consequence of ignorance, or in ignorance of certain particulars. When an agent acts in ignorance and does not know what is for her own good, such an action is not classified as an involuntary action. Only an action which is a consequence of ignorance of particulars is classified involuntary. These particulars include information about the agent herself, the act, the object or the range of the act, the instrument of the act, the effect or result of the act, and the manner in which the act is conducted. An agent ignorant of any one of these particulars could be seen as acting involuntarily, but the act itself and the object or range of the act are the more important particulars surrounding the act. There would, according to Aristotle, be no difference between the voluntariness of a wrong act either calculated or done impulsively.

Aristotle used the term pro-airesis or deliberate choice to explain his theory. According to him choice is certainly voluntary, but choice and voluntary are not interchangeable terms. Voluntary has a broader connotation, explained in the following terms: a man who acts because of desire, does not do so as a result of deliberate choice, in contrast with the man who is master of his passions. The object of desire is usually painful or pleasant, whereas the object of choice is neutral. Choice is also not interchangeable with wish - to wish involves impossibilities and is directed towards ends and not means. A choice is attainable, and could be accomplished by an agent's own efforts. Choice is not associated with opinion, because opinion is seen as true or false, which could be said about anything. Choice on the other hand, is always about something attainable, whether good or bad. When praised, an opinion shows the way by which it has been arrived at. Choice is therefore not just a kind of opinion, but rather defined as a 'voluntary act preceded by deliberation' (Aristotle 1955:84).

Deliberation is explained by Aristotle to be possible only in a reasonable person. It does not concern eternal things or things in regular motion. Neither does it concern happenings in regular sequences nor when something happens as a result of an accident or luck. Deliberation only happens about outcomes we can influence by our action. 
'Deliberation then, is concerned with things which, while in general following certain definite lines, have no predictable issues, or the result of which cannot be clearly stated, or in which, when important decisions have to be made, we take others into our counsel, distrusting our own ability to settle the point (Aristotle 1955:86).'

We deliberate only about outcomes we can influence by our actions. We deliberate about the best, easiest or most effective way to attain a specific end. We have to deliberate before we can choose, although both choice and deliberation are focused on the same end. Choice leads to the desire to act. Pro-airesis is:

'the deliberate desire of things in our power (Aristotle 1955, book III:27)'.

Aristotle is of the opinion that it is at all times within our power to be good and to do right. In a similar way, it is at all times in our power to be vicious, i.e. full of vice. We deliberate and choose the means to our goal or end. The actions that follow are voluntary and done through choice. The way that we choose, whether we choose virtuously or viciously, depends on ourselves. Vices and virtues are attainable by our own exertions.

But according to Kant (Paton \& Kant 1991), the qualities of temperament and person, i.e. the vices and virtues, are not under control of the will and therefore irrelevant to moral judgment. The virtues and vices are 'states of character, which influence choice, but are not exhausted by the disposition to act deliberately in certain ways' (Nagel 2007:359). The only proper (Kantian) object of moral assessment is the determination of the will by the motive of duty. Even if impulses secondary to vices are controlled, one still has the vice. This does not mean that the product of earlier choices is not amenable, but an agent's constitution is largely seen as bad fortune. And yet, people are still judged for such qualities because they are assessed for what they are like. These moral judgments are irrational, but involuntary.

There is also according Eshleman (2004) the notion of 'appropriateness' that is not explained unambiguously by Aristotle. When is it appropriate to praise or blame an agent? Two views exist on this matter, one explaining appropriateness by alluding to an agent that 'deserves' praise or blame according to her character or personal 
traits, and the other dealing with the consequences of the action, leading to praise or blame, which in turn may bring along a change in behaviour. These views are subsequently characterised as merit-based views and consequentialist views, which are traditionally defined as compatabilistic of nature.

\section{The history of determinism}

The difference between fatalism, which Aristotle recognised as a threat, and causal determinism, is that followers of determinism believe that while everything is caused by antecedent conditions, an agent's own actions are needed in the chain of events. Therefore, by deliberating, choosing and acting, one indeed contributes to the overall state of things, but this state is predetermined. Human action is therefore not otiose, but neither is it voluntary.

Causal determinism was traditionally divided into scientific and theological doctrines. Until the first half of the twentieth century, a distinction was made between moral responsibility theories compatible with determinism and those which were incompatible. Compatibilist views were originally supported by the Stoics, and later by Hobbes, Hume and Mill (Eshleman 2004). These theories were traditionally seen as consequentialist in nature. The incompatabilist theories in comparison, were seen as merit-based and supported by Epicurus, and later on by Augustine, Reid and Kant (Mason 2005).

In the last fifty years, the assumption that a single concept of moral responsibility exists has been challenged. Alternative versions of merit-based views have been developed. The distinction between holding someone responsible and someone being responsible has been elaborated upon. "Holding responsible" encompasses the attitudes and actions, as well as the emotional states associated with the practice of assigning praise or blame to a moral agent. These states should be independently assessed when someone is judged to have satisfied certain conditions of being responsible. For a consequentialist, these conditions entail that the agent is influenced by praise or blame to change her behaviour, whereas for the merit-based supporter, the conditions are dependent on the agent's ability to make a decision to 
act otherwise. The practice of holding a person responsible necessarily rests on the qualification that the person has independently been judged to be responsible.

By definition, compatibilism then means that even when actions of moral agents are caused by outside events, the ascription of moral responsibility still makes sense (Mason 2005). Two questions arise, namely: (1) what are we doing when making judgments about moral responsibility? Mason attempts to answer this question by discussing non-cognitivist and cognitivist views on moral responsibility. Noncognitivist views are traditionally not classified as compatabilist, but in some cases the theories are so intertwined that it becomes difficult to differentiate between compatabilistic and non-compatibilistic views. She therefore includes non-cognitivist views in her discussion.

Peter Strawson is a typical non-cognitivist, holding the expression of attitudes as the benchmark of his theory. 'We emotionally react to what we perceive to be the quality of other people's wills' states Mason (2005:344) as a summary of Strawson's opinion. On the other side of the spectrum lie cognitivist views, implying that a moral agent has to make a cognitive judgment that certain conditions obtain to be deemed morally responsible. The question then is: (2) what excuses someone from being morally responsible? Mason highlights certain conditions that should be considered when answering this question. These conditions include discussions on action, autonomy, intention, agency, weakness of will, moral luck, and the principle of 'ought implies can'. Further discussion will be based on Mason's differentiation between non-cognitivist and cognitivist theories.

\section{Non-cognitivist theories}

Strawson (1962) makes it clear that the truth about determinism, whatever it may entail, is not known, but explains his theory of moral responsibility from a compatibilist's point of view. He defines himself as an optimist filling up the theoretical 'lacunae'. He bases his theory on what he calls reactive attitudes, i.e. the attitudes and reactions of people involved in communications and transactions with each other. These attitudes depend on individuals' beliefs about interpersonal relationships, and include love, resentment, hurt, gratitude and forgiveness. 
He discusses the influence that a generalised theory of determinism would have on the reactive attitudes. He is adamant that a clear definition of determinism has not been formulated, but states that whatever definition may be used, it would mean that such a definition should be applied to all actions or attitudes. It would mean that the reactive attitudes should be reduced to objective attitudes in every sense of the word and at all times, if such were the definition. This consequence of a specific interpretation of determinism would be practically inconceivable, and humanly impossible. We do not and cannot adapt the objective attitudes because of a belief held. We are not and cannot be objective to everyone and if we are to become objective, it is only in specific cases, e.g. with children or other morally incompetent persons, and not because of a theoretical convention. If determinism were true, what would then be rational? There would still be human commitment to the reactive attitudes and moral persons would tend to choose rationally for the reactive attitudes.

Strawson's description of the reactive attitudes contributes to moral responsibility theory by taking the personal attitudes or psychological dispositions of individuals into account. His views are however criticised because of the insular nature of the theory of reactive attitudes, which are defined as natural responses and therefore cannot be dislodged by external theoretical considerations (Mason 2005).

For Wallace (2002), moral competence is defined by the capacities to grasp moral reasons, and then control behaviour accordingly. These capacities are termed powers of reflective self-control. The practice of "holding responsible" must be interpreted while regarding the reactive sentiments defined by Strawson, which Wallace argues to be connected to certain expectations. This connection lends a cognitive dimension to the reactive sentiments. To hold responsible therefore means to hold someone to certain expectations. These expectations are the moral demands accepted in society. He argues that the question of being responsible is of normative character: to be responsible is when someone can be held responsible in a fair way; fair being dependent on the conditions of reasonableness and deservedness. When regarding moral responsibility theory in this sense, he deals with the intuitions generally leading to strengthen the incompatibility theory. In his 
opinion, it is only unfair to hold someone responsible when such a person has impaired reflective self-control, and not, as is traditionally seen in incompatabilist theory, where the lack of alternative possibilities inform the unfairness of ascribing responsibility. He summarizes his theory by saying (2002:681):

'... moral responsibility is a matter, not of freedom of will, but of a distinctive kind of normative competence: the general capacity to grasp moral reasons, and to guide one's conduct by the light of such moral understanding.'

Thomas Nagel (2007) also developed a non-cognitivist theory characterised by the expression of attitudes, but in contrast to Strawson based it on the Kantian notion of moral responsibility (Paton \& Kant, 1991) where the agent is required to be in control of circumstances for which she is assessed. Neither good nor bad luck should influence the assessment, but this kind of ascription is sometimes counter-intuitive, for an agent's actions are judged more kindly if the results or consequences of the action turn out favourably. Nagel notes that our choices as influenced by elements of character, i.e. beliefs, desires and dispositions, are shaped beyond our control by genetics, parents, cultures and social pressures. If Kant is correct, then only choices uninfluenced by luck are to be deemed morally responsible and it is virtually impossible to distinguish any such choices. Therefore, either Kant's criterion should be abandoned or the common-sensical appraisals of persons and actions should be discarded. Not only our actions, but also our opportunities and choices are influenced by external factors which are not produced by our will and which do not usually excuse moral judgment. What we do is limited by our choices and opportunities which are determined outside of our control. Nagel defines moral luck as (2007:356):

“... Where a significant aspect of what someone does depends on factors beyond his control, yet we continue to treat him in that respect as an object of moral judgment..."

External influences therefore undermine moral assessment in such a manner that almost nothing is truly left under a person's control. The condition of control may thus be said to be false because the hypothesis is initially plausible only to be refuted by counter-examples. A more refined condition is needed, a condition that elaborates on the kinds of lack of control a person may experience. The sense that 
moral luck is paradoxical is however not a mistake. One intuitively accepts conditions of moral judgment which, if consistently applied, threaten to undermine the ordinary standard. Nagel clarifies this by stating:

“... because there are various respects in which the natural object of moral assessment are out of our control or influenced by what is out of our control, we cannot reflect on these facts without losing our grip on the judgments (2007:357)."

When judging cases of decision under uncertainty, should one therefore subtract the effects of occurrences subsequent to the choice, and concentrate on the decision made in the light of probabilities of outcome? This practice would break down each act to the essential core, "an inner act of pure will assessed by motive and intention" (2007:359), but it will be contrary to actual commonsense judgments. According to Joel Feinberg (1968) the domain of moral responsibility should be restricted to the inner world, but even by doing this the domain will still not be immunized to luck or causal determinants. For luck also influences decisions and not just actions.

A person is judged for what is actually done, not what could have been done in different circumstances. Nagel says:

"This form of moral determination by the actual is also paradoxical, but we can begin to see how deep in the concept of responsibility the paradox is embedded. A person can be morally responsible only for what he does; but what he does results from a great deal that he does not do; therefore he is not morally responsible for what he is and is not responsible for. (2007:360)"

There is an obvious connection between moral responsibility and freedom of will. How can one be responsible for acts of the will itself, if the will is also the product of antecedent conditions outside of one's control? The area of genuine agency 'shrinks away to an extensionless point' (2007:360). This result seems unacceptable, but the fact is that a person is morally judged, not by his existence or his character traits. When this judgment or assessment is concentrated on what is under the person's control, his 'responsible self is swallowed in the order of events' (2007:360). Thus the actual self is undermined. 
Feelings about ourselves and others and moral attitudes are however still present and not undermined by a lack of control. This is a similar sentiment to the reactive attitudes by Peter Strawson (1962). We view ourselves not just as portions of the world, necessary links in a chain of events, but we experience definite boundaries between us and the world as such. We cannot only have the external evaluative view of our selves. This stays true even if we are not responsible for our own existence, our nature, our choices or our circumstances. Those acts are still ours, and we are still our selves, despite reasons that argue us out of existence. This internal view of our selves is extended to other persons in the form of the reactive attitudes. This means that we refuse to be limited to external evaluation, but we operate in a world where the external view is forced upon us because we are part of this world of aligned causes. What subsequently follows is "the gradual erosion of what we do by the subtraction of what happens" (2007:361). The concept of moral luck should therefore be expressed taking into account the concept of agency, as well as the connection to internal moral attitudes.

\section{Incompatibilist theories}

Galen Strawson (2007) describes a dilemma where, even if determinism is false, which leads logically to the conclusion that events then must happen at random, agents are still unable to control decisions and actions because all is due to chance. He agrees with Nietzsche (1973):

\footnotetext{
"The causa sui is the best self-contradiction that has been created so far, it is a sort of rape and perversion of logic. But the extravagant pride of man has managed to entangle itself profoundly and frightfully with just this nonsense. The desire for 'freedom of the will' in the superlative metaphysical sense, which still holds sway, unfortunately, in the minds of the halfeducated; the desire to bear the entire and ultimate responsibility for one's actions oneself, and to absolve God, the world, ancestors, chance, and society involves nothing less than to be precisely this causa sui, and with more than Baron Munchhausen's audacity, to pull oneself up into existence by the hair, out of the swamps of nothingness..."
}

For Strawson, the basic argument which shows ultimate moral responsibility does not exist, irrespective of whether determinism is true or false, is set out in the following way: 
1. Nothing can be causa sui, i.e. self-created

2. To be ultimately morally responsible logically means to be causa sui (at least mentally)

3. Therefore no-one can be ultimately morally responsible.

Neither heredity nor exposure is controlled by the person herself. A person cannot hope to change later in life to accede moral responsibility which is determined by heredity and experience. Both trying to change and success in trying is determined by being the way one is according to heredity and experience. After initial changes in a person's character, all again is determined via the initial changes dependency. A person can be influenced by random factors, but not influenced or changed to become morally responsible. People can thus change, but not to become ultimately morally responsible. Therefore in the most fundamental sense, no punishment or reward can ever be truly fair, but the practise of praise and blame is practical and indispensable in legal and non-legal ways.

Strawson does acknowledge that every person is confronted with situations in everyday life where it makes practical sense to punish or blame and where the feeling exists that there is freedom and choice at a very specific point in time. It is important to realise that whatever the metaphysical argument about moral responsibility may be, at a specific point in time one will feel the freedom of choice, whether it may be retrospectively determined or not. Certain philosophers may argue that the feeling of being free is evidence enough to prove that an action truly is caused by an agent's free will, but feeling free does of course not entail being free. It only means that the agent is unaware of the probable causes of his action, but the feeling of being free cannot deny such causes (Ayer 2007).

To Richard Taylor (2007) determinism is "whatever occurs under conditions given which nothing else could occur" (2007:340) and incompatible with responsibility and obligation. His argument is:

1. only to human conduct can moral responsibility be ascribed

2. it is a necessary condition for such a human to could have done something else (but not a sufficient condition), i.e. the occurrence of his action is contingent 
3. since (b) is never fulfilled because of determinism

4. moral responsibility cannot make sense

Some philosophers say that a sufficient condition for moral responsibility is the deliberative act of an agent, knowing what the consequences of the act might be. This assumption can only be true if the act is contingent according to Aristotle (1955), who said it is only sensible to deliberate about contingent things. Since behaviour, deliberation and beliefs are all causally determined, it does not fulfill the criterion. According to Taylor, it is also illogical that a man cannot be responsible for his decisions, but still be responsible for his actions as some believe. Either he must be responsible for all, or not responsible.

He is however of the opinion that indeterminism is also not compatible with moral responsibility, for when an agent's actions is the outcome of mere chance, a random occurrence, he cannot be held responsible for the action. This random occurrence is totally beyond his control and unpredictable.

What then, is needed to salvage responsibility? A theory of agency including a reason for everything, with some of it contingent. The only possible answer is an agent performing an act, but not causally necessitated to do so, in other words, the agent's action is not part of a series of events. This theory of agency involves a conception of a self/a person/an agent who acts, where the agent is defined as a non-event leading to an event (the action). The person (or agent) is something else rather than a sufficient condition; the agent performs an act, but does not cause it. This does not happen in the physical world, but may be reminiscent of Reid's active power, or Kant's noumenal self, or even Aristotle's self-moving (Taylor 2007:342).

How can agency be compatible with moral responsibility? It can only be compatible if (a) some acts are contingent (which can be possible), (b) if only humans can be morally responsible, and (c) acts are not capricious. Causal conditions cannot be equal to motives or purposes. The concept of agency cannot be compared to a random selection, for with agency an explanation can be given. If agency can be intelligible, then moral responsibility can indeed be possible. 


\section{Real self views}

Mason (2005) separates compatibilism into views from a real self perspective, which try to show that we hold an agent responsible when her action issues from her 'real self', and views from an intellectual process perspective, which claim that the agent must go through a sort of intellectual process when acting, to be assumed responsible. When talking about the real self views, the obvious question is - what is the real self? According to advocates of this view, if an action originates from the real self, only then can the agent be held responsible for the action.

When Frankfurt (1971) discusses his theory of the real self, he uses the term to describe action due to second order volitions, or higher order desires. This means that a moral agent needs to desire that her first order volition is effective, or followed through. A first order desire is the desire to have or to do something. Second order desires are the desires one has about first order desires. Freedom of action and will means the governing of actions by first order desires, and the governing of first order desires by second order desires.

He also uses his theory to argue against the principle of alternate possibilities. Frankfurt defines the principle of alternative possibilities as:

“... a person is morally responsible for what he has done only if he could have done otherwise" (1969:829).

This definition accepts that moral responsibility and determinism are incompatible. It is however, according to Frankfurt, false. Sometimes a situation can lead to a person doing something because the circumstances make it impossible not to do so, and in other cases the person has no alternative available, but the circumstances do not lead to, i.e. do not become the reason, for her performing the action. In situations like these, moral intuitions tend to disconfirm the principle of alternative possibilities.

If one takes the example of coercion as a special type of application of the principle of alternative possibilities, someone may not be able to do otherwise because of the circumstances, i.e. coercion, and/or such a person may not be morally responsible 
for the action either. But simply because the person is not able to do otherwise, does not entail that she is morally not responsible. In the Frankfurtian examples, a person might go through the action in the presence of the coercive power, but it does not necessarily mean it is because of the coercive power that she went through with the action. The crux of the matter is to determine what the reason behind the action is - circumstances might make it impossible to avoid an action, but these circumstances do not have to be the primary motive for the action.

Frankfurt therefore proposes a new principle in stead of the principle of alternative possibilities, which he defines as follows (1969:838):

"... a person is not morally responsible for what he has done if he did it only because he could not have done otherwise."

This new definition does not conflict with the view that moral responsibility is compatible with determinism.

Frankfurt's view is typically seen as the hierarchical view of the real self, i.e. an agent acts according to a hierarchy of desires. He struggles however to clarify his view of the real self, sometimes stating an agent's action should be 'wholehearted' to be judged as responsible, otherwise saying an agent should be satisfied with her second order volitions for her to be responsible (Mason, 2005).

For Fischer (1999), causal determinism is consistent with responsibility even if there are no alternative possibilities of action. Human beings are morally responsible, and this should be independent of scientific doctrine. He says (1999:129):

" The precise form of the equations that describe the universe, and whether or not they are or correspond to universal generalizations, are not the sorts of thing that should be relevant to our most basic views of ourselves (as morally responsible agents and thus apt targets of the reactive attitudes)."

The reactive attitudes and morally responsible agents are therefore resilient against science, enforcing the difference between moral agents (humans) and animals. Fischer agrees that the Frankfurt-type cases ensure that alternative possibilities are not necessary for moral responsibility, and the falsity of determinism does not entail 
the lack of control needed for moral responsibility. Human beings are therefore morally motivated by resiliency. He terms himself a "supercompatabilistic semicompatibilist" (1999:130), reflecting the complexities of responsibility theory.

Susan Wolf (2007) is of the opinion that not all aspects of luck can be eliminated she is a compatibilist by definition, and believes that we are responsible for our actions and the consequences of our actions only if the actions are within our control of will, of our deeper self. Our deeper self includes "those attitudes about the sort of person one really is, and really aims to be. ...These two conditions must be supplemented by a third, namely, that one's deeper self is sane" (Shafer-Landau, 2007:339).

Free will and responsibility is also of practical concern for non-philosophers (Wolf, 2007). It seems apparent that in everyday life the conditions of moral responsibility are known where it usually comes down to questions of application, i.e. does this person meet this condition? In contrast, the conditions for moral responsibility are not clear from a deterministic perspective, where the question of whether we can even be held responsible for anything dominates. She therefore urges the philosophical community not to leave the prephilosophical conditions behind, especially the condition that a person must be sane to be responsible. Instead of the causa sui condition which has its obvious problems, she therefore insists that a condition for moral responsibility should rather be that of sanity.

For Frankfurt, the freedom of action should be stated against the freedom of will, where freedom of action encompasses the freedom to do whatever one wills to do. These actions can only be morally assessed if the action is truly under the agent's control, in other words, she is acting according to her own desires. The question about freedom of will logically follows, where it is defined as "the freedom to will whatever one wants to will" (Wolf 2007:364).

According to determinism, our behaviour is determined by desires, which are in turn determined by something else and are therefore not really our own, or only our own superficially. The deep self view distinguishes between desires from the real self and foreign desires. Still, the question remains, who is responsible for the deep self? 
Some may answer even a deeper self, but surely this cannot continue ad infinitum? There is a psychological and a logical limit to the number of levels of reflection, and there will always be a last level, for which something or someone must take responsibility. According to determinism, something 'outer-self' is responsible for this last level. Even if determinism is not true, the deep self is still not determined by me (unless the condition of causa sui is true, which is illogical) and therefore must be explained by random mutations or chance. I am therefore neither responsible for my existence nor in control of my deepest self, independent of the theory of determinism. The holders of the deep self view, Frankfurt in particular, may however ask the rhetorical question (2007:367):

"If you are free to control your actions by your desires, and free to control your desires by your deeper desires, and free to control those desires by still deeper desires, what further kind of freedom can you want?"

At this point, Wolf introduces the condition of sanity into her theory of responsibility. She is of the opinion that the deep self view on its own is not a sufficient condition for responsible agency. She states that the necessary condition is that of sanity. The desire to be sane can be defined as "the desire to be connected to the world in a certain way" (2007:368), where legal criteria for sanity are that an agent (1) knows what he is doing and (2) knows what he is doing is wrong or right. These conditions can lead to an accurate conception of the world. Sanity could therefore be understood to be "the minimum sufficient ability to cognitively and normatively recognise and appreciate the world for what it is" (2007:369).

Wolf constructs a theory she calls the sane deep self view. As mentioned before, the deep self view is a necessary condition for the ascription of moral responsibility, but not sufficient by itself. She proposes that the gap, which cannot be filled by a metaphysical impossibility like causa sui, could be filled by the condition of sanity. Incorporating this condition could help to explain why individuals with a deprived childhood or from misguided societies are not morally responsible for their actions. What is implicit in the sane deep self view, is the ability to correct our selves, thereby doing something between self-revision and self-creation. We cannot be metaphysically responsible for our selves, but at least we can be morally responsible, 
implying the ability to understand right and wrong, and to change our characters accordingly. So to be responsible for our selves, we need to fulfill two conditions:

1. The ability to evaluate our selves in a sensible and accurate fashion, i.e. to be sane

2. The ability to transform our characters according to this evaluation, which is possible because of the superficial control we deem realistic by our deeper selves (Wolf 2007:371).

In this sense, we can take responsibility for the selves we are, but not the selves that were created. These conditions can however only be valid if the deep self is sane.

Two objections are apparent when studying the sane deep self view, the first being the condition of sanity. How can this condition of sanity be generalised? Is it only because of a widely intersubjective agreement? Or because of our (and by our meaning that of "sane individuals") apparent success in going around the world? The second objection is closely connected with the opinion that sanity is equal to being right about the world. Is anyone who has false beliefs or acts wrongly insane, and subsequently not morally responsible? And who decides what false beliefs or wrong acts are?

Wolf answers these objections by stating that the strength of the condition of sanity lies in its normativity, but she realises that other reasons for acting irrationally should first be investigated before a person could be labeled insane and therefore not responsible. That is why she defines sanity as an ability, including normative and cognitive values, which implies that any individual could still choose not to make use of the ability. She does note that defining it in such a way, may again bring forth the metaphysical problem of determinism (because who determines which choice will be made?), but at least the scope of the problem is slightly narrower. In the end, why care if responsibility is not as we imagined it to be? Responsibility stays a normatively significant aspect of our lives, with its demands somehow binding and relevant to us. 


\section{Intellectual process views}

The other leg of compatabilism (Mason, 2005) is called the intellectual process view, where an agent must go through an intellectual process to be seen as morally responsible. Ayer asks the question whether every event must indeed have a cause. Universal causation is certainly not prescribed for scientific thought (Fischer 1999), and it could be possible that causal laws explaining every event in the universe do not exist. In humans only a few actions are completely predictable. The complete explanation of everything in the universe is theoretically attainable, but until a specific explanation is found, it could be possible that no explanation exists (Ayer 2007).

Ayer defines a constrained action as an action for which an alternative exists, and for which the agent has the power of choice, but the consequences of the alternative seem less desirable than the action she is led to take. A constrained action can also be one where habitual ascendancy leading to a habit of obedience leaves the agent with no power of choice. Only when an action has a special cause, i.e. is constrained, the agent is not free. So when an agent acts in a certain way his action may be determined, but if it is not constrained as per the conditions given, he can still be reckoned to be free. Ayer asks the question whether it is not arbitrary to distinguish one type of cause from another (constrained or not), but argues that the conditions of constraint in itself are sufficient to differentiate between constrained action and non-constrained (but caused) action.

According to Ayer, determinism means that events are factually correlated and not that these events are in the power of one another. If one type of event occurs, then another type will occur. These events are always in a tempo or tempo-spatial relationship. The antithesis between causality and freedom therefore only exists because of metaphors used to elaborate the relationship between events. Nevertheless, if determinism is valid, then the future is explained in terms of the past. Knowledge of the past can be used to predict the future and the future will already be decided. Does this necessarily mean that one becomes "a helpless prisoner of fate" (2007:354)? He answers this question by explaining the meaning of 
a decided future - it is not a sequence of events that someone has arranged. It is certainly possible to deduce aspects of the future by looking at facts about the past, and combining these facts with general (natural) laws. This then entails that man is not a 'helpless prisoner of fate'. It does also not mean that man's actions make no difference to the future, for these actions are causes and events. It only means that man's behaviour can be predicted in a rough sense. To say that behaviour can be predicted, does not however mean that it is under constraint, and therefore man is still free.

Hilary Bok (1998), a Kantian compatibilist, has a set of standards by which to evaluate options. In her opinion, the more important issue is practical moral responsibility and not the theoretical discussion about determinism. The knowledge that there are (or are not) alternative possibilities available, is not readily available. This means that any person at any specific time will act as if she has many different alternative options. She therefore acts as if she has many different choices, and as if she has free will. She acts as if 'I can do whatever I would do if I chose to' (Mason 2005:350). In her action, she always chooses one action above another, even if theoretically the other action cannot happen.

Manuel Vargas (2005) is of the opinion that pre-theoretical intuitions could not all be accommodated in a moral responsibility theory. Some of these intuitions should be abandoned, while others are incompatibilist and therefore may not be realistic. Revisionist theories must become more important in moral responsibility theory. In the process of revisionism, the real self views and the intellectual process views are moving closer together. The more we think about why real self views are important, the closer we get to the intellectual process of the agent when acting. At least some of the compatibilist views are successful and normative questions should therefore be addressed.

Revisionism, and specifically paradigmatic revisionism, allows for a difference in diagnostic and prescriptive views about moral responsibility, i.e. we are thinking one way, but should be thinking another. Any revisionist theory should specify which condition of moral responsibility it applies to and if this condition is changed, could 
the resulting theory still be termed a theory of responsibility. Responsibility is a fundamentally moral notion, and any revised account should therefore use a nonresponsibility dependent position from where to revise.

\section{Discussion}

Aristotle based a first moral responsibility theory on the concepts of voluntary action and deliberate choice. For him, it is always possible to deliberate and choose one's means and therefore ends. Either vice or virtue is always a possibility of choice, and both are attainable. As a starting point of the discussion of determinism and free will, these concepts are utterly important. However, Aristotle does not really discuss the determinism issue, although he recognises fatalism as a threat to moral responsibility. If determinism is true, according to whichever definition is used, it is difficult from a theoretical perspective to prove that deliberation and choice is free. Kant's contrasting opinion that these vices or virtues are irrelevant to moral judgment is also proven to be mistaken when practical judgment is considered. In everyday life, human beings are judged according to their current qualities, however strange it may seem on a metaphysical level.

Peter Strawson's reactive attitudes make perfect sense - of course it is necessary to regard these emotional components when constructing a theory, because human beings cannot and will not be exclusively objective. However, the criticism that his theory cannot be dislodged by external evaluation is valid. Wallace's incorporation of a cognitive element strengthens Strawson's theory, since human beings are intellectual and emotional beings and both these components should be accounted for. Nagel's criticism of Kant's opinion that man cannot be judged on outcomes outside of his control is sound. However, I am not convinced that the introduction of agency alone would render his theory complete. Taylor also elaborates on the concept of agency, stating that an action, in his theory, is not part of a series of events. This could however not be true in the physical world as we know it, and the question arises of how practical this knowledge is.

Galen Strawson uses the causa sui clause from Nietzsche to argue that no person can ever be ultimately morally responsible, because only a person who is self-created 
could be thus. He does, however, recognise the reality that people will still feel they have a freedom of choice in any particular circumstance independent of their ultimate moral responsibility.

For Frankfurt, the motive behind any action is the ultimate determinant of responsibility. With his Frankfurtian examples, he makes it clear that alternative possibilities are not needed for action to be free. Fischer contributes by saying that humans should be responsible, irrespective of any scientific findings and Ayer agrees. He also states that any action that is not constrained is free; that even in our predictable world, behaviour can be predicted, but not action. I agree with Fischer and Ayer in the sense that science does not need to answer all the questions (yet), but I am not sure whether Ayer's second premise contributes in a real sense to moral responsibility theory. Hillary Bok's statement, that any human being acts as if she has many choices anyway even if theoretically it cannot happen, makes sense, although begging the question of freedom of action.

For Wolf, actions within the control of a sane deeper self could be deemed our own and we should therefore be responsible for it. We have the ability to correct our actions and in a sense, our characters,, and therefore may not be ultimately responsible if it cannot be shown that we are free to choose as individuals, but certainly could be and should be responsible on a moral level as part of our daily interaction. I do agree with Wolf with having responsibility on some level, as a person who makes choices every day, acts in certain ways, and is praised and blamed for these choices and actions. This may not mean that I am ultimately and universally responsible for my choices and actions, and my choices and actions may, and probably are, determined, but when interacting with other people on a practical day-to-day level, and as part of a society where the ascription of responsibility is needed to ensure law and order, I should certainly be held accountable for my actions. Wolf's definition of sanity does however, need to be clarified. To say that a sane person is one who is deemed sane by a majority of the societal members, is not clear enough, especially since the labelling of a person as insane has extensive consequences in a typical Western society. 
In my opinion, Galen Strawson and Thomas Nagel (with reference to Peter Strawson) have the soundest arguments on individual moral responsibility. I would suggest a theory that recognises the triviality of consistent determinism or randomness, and rather focuses on the way forward from Galen Strawson's Basic Argument in the first account. Whether determinism is true or false, one is still often faced with situations of choice where an immediate decision and subsequent action is needed. In these situations ultimate responsibility becomes irrelevant because one is faced with a choice in a situation where a decision must be made in that instant regardless of whether the choice is determined or not. That instantaneous choice and action will lead to consequences which one may or may not foresee, but in that moment, an individual must take action to his best ability. Whether alternative actions are available or not, or whether the consequences are truly attributable to the specific individual should not be of our concern. Our concern should lie with the individual's ability to choose an action given the information available at that specific point in time. An action must be taken, either one way or another, and any given individual would not be able to substain from any action at all because that would mean that such an individual would freeze on the spot, and by choice, not move ever again which is impractical and unimaginable. The discussion of whether action necessarily entails movement, is however not part of this thesis.

Secondly, whether the deep self can become a deeper self ad infinitum, is inconsequential. What is important to realise, is up to a specific deep self (say the fourth) one could be responsible for decisions and actions, although not ultimately responsible for the universal causal chain of events. All sane human beings, applying Wolf's condition of sanity, could then be responsible for their deep selves to the fourth (or $n^{\text {th }}$ ), but not the last, or ultimate, abstraction which could not be determined or defined in our current level of technological sophistication and subsequent level of thought process, and may never be defined. In a sane society, as we regard our own, one would therefore be able to trace any individual's choices and actions up to a certain level and accord praise and blame accordingly up to that level according to the specific action and the consequences of that action taken. In a society where law and order depends on the attributability of blame, this approach 
would therefore give ample evidence to blame an individual for a specific choice, action and the connected consequence in a practical sense. Whether law and order should depend on the attributability of blame, is also not in the scope of this discussion.

Whether we are ultimately responsible, is therefore of no consequence to me. Most of us have the ability to understand wrong and right, and to change our perspectives and characters if needs be. The answer to the conundrum may therefore never be found, but on a practical level every person has to make choices, whether they are real or only seem real, and every person has to act according to these choices. Moral responsibility may therefore be unattainable, but pragmatic responsibility is not. The next chapter deals with pragmatic responsibility in the medical world from an individual and collective's perspective. 
You sound to me as though you don't believe in free will,' said Billy Pilgrim. 'If I hadn't spent so much time studying Earthlings,' said the Tralfamadorian, 'I wouldn't have any idea what was meant by free will. I've visited thirty-one inhabited planets in the universe, and I have studied reports on one hundred more. Only on Earth is there any talk of free will.

Kurt Vonnegut, Slaughterhouse-Five 


\section{Chapter 2 - Medical responsibility}

\section{Introduction}

Traditionally medical ethics is primarily concerned with the duties of the physician towards the patient, i.e. the physician-patient relationship, which occurs in isolated dyads (Pellegrino 1982). Responsibility is not shared and the medical institution serves as a workshop only which facilitates the work of the physician and in which the administration of the institution supplies resources, but does not intervene in any moral decision-making processes. This traditional view ignores the fact that "medical decisions take place in a context of intersecting value systems, of the patient, the family, the society, culture and government" (Pellegrino, 1982:3). Moral agents other than the physician and the patient's moral values and moral agency should be taken into account, and the dilemma of morality in situations of collective judgment should be addressed. This dilemma is more pronounced in a democratic, educated and technologically advanced society where the practice of medicine in itself is complex, and dependent on institutions for resources and on other professionals for their knowledge and skills input. Newton (1982) is of the opinion that there is no need for a metaphysical or even a logical issue regarding collective responsibility - in everyday society, it is often found that individual acts register as an act of a collective or corporate entity. This may indeed be the case, but a proper theoretical background for the ascription of collective responsibility cannot be disregarded.

In this type of community where moral decisions and actions take place in collectives, physicians' moral roles are no longer autonomous. When a physician practices within the hospital environment, the facility is mostly provided at the community's expense for the community's purposes. Hospitals are naturally subject to policy changes and implementations from the government, but these policies should benefit all patients. The hospital administration thus shares in the responsibility of patient care through policy implementation and other administrative duties. The physician is not only part of the medical team deciding over the fate of a single individual (where he is dependent on the opinions of other 
professionals), but also part of a profession which necessarily means he should abide by the profession's code of ethics, mission, decisions and policies and that he takes part in the profession's responsibilities. The physician could also be part of a medical school, another collective, where he shares in the responsibility of teaching, research, and the quality of graduates and medical officers. Although the allocation of resources would not be his primary responsibility but rather that of public policymakers, he can by way of input influence these policies in a direction favourable to the patient.

Collective decisions are part of the daily concern of physicians and other specialists everywhere. These decisions can affect the individual doctor's responsibility, and his decisions and actions towards his individual patients, but should still be incorporated in a broader theory of medical morality. Its application with the central theme lies in the realisation that an individual physician is judged not only by his individual responsibility, but also that of the profession, the medical team and the hospital. He may also work in the state service, which makes him part of an even bigger collective. Any individual in the healthcare system has different roles to play: as individual, but also as a member of different collectives. This chapter's discussion focuses on responsibility in healthcare from such an individual's perspective.

Firstly, questions about responsibility in the healthcare setting will be discussed, and then Pellegrino's framework (1982) will be used to investigate questions about responsibility in healthcare. This discussion will include a brief summary of the history of collective responsibility as a concept, which is important to highlight since responsibility in the healthcare setting deals with medical professionals acting as individuals, and therefore being ascribed individual responsibility, and acting as professionals and therefore as part of a number of collectives. Collective responsibility is ascribed to medical professionals for a number of roles which they form part of. Whether this ascription of collective responsibility is fair, will be discussed in the subsequent sections of this chapter. In the last chapter of this thesis the theoretical knowledge regarding individual and collective responsibility in the healthcare setting will be applied to dr Thys von Mollendorff's case study. 


\section{Questions about responsibility in healthcare}

For Pellegrino (1982:5), the following questions should be addressed when discussing responsibility in healthcare:

1. How is moral agency and responsibility allocated in the realm of collective decisionmaking in the healthcare setting?

2. How is each members' moral agency influenced by the collective - when she disagrees with the collective, how far should she cooperate and when should she dissociate herself from it?

3. To whom is moral responsibility primarily due, and how should conflict between groups be resolved? Moral responsibility could be due to:

a. The patient, person or group served by the physician and/or his institution

b. The physician's partners in the decision-making process

c. His own moral beliefs and principles

In the medical world, urgency and the possible damage following an unethical or immoral decision leads to a rapid need for resolution of these conflicts. Without clear answers to the above mentioned questions, responsibility in the healthcare setting could be infinitely diluted, or an attitude of passive compliance may be adopted.

Questions about moral responsibility in the healthcare setting become more complex still because of the typically increased knowledge of one of the members of the medical team, i.e. the physician, but who is fast becoming more and more dependent on other professionals to help him make his decisions. However, the patient's well-being is still the primary goal of any healthcare professional and facility, and has high preference above distinguishing between roles and authoritative figures within the system.

It remains a problem of how far responsibility can be traced back when more than one person is involved in a decision-making process - who is ultimately responsible for a shared or discussed decision? This does not mean that the era of individual decision-making processes in the form of physicians deciding individually about their patients' outcome has come to an end. These individual decisions must still be made 
and actions taken, but it now happens within the context of complex collective systems where a common denominator of accepted principles could help to attribute responsibility, resolve conflict and determine moral agency (Pellegrino, 1982).

Six interacting levels of moral agency and decision-making processes can be identified in the healthcare setting (Pellegrino, 1982), viz.

1. The ethics of the healing relationship, where a mutual obligation exists between the physician and the patient.

2. This is set within the context of collective decision-making, i.e. the ethics of collective medical decisions.

3. Then, each profession has its own set of rules and obligations, i.e. nursing ethics, physician ethics, therapist ethics, etc.

4. Specific moral-medical dilemmas need resolution, for instance abortion, euthanasia and others.

5. The beliefs, values and principles of individuals derived by reason, i.e. philosophical ethics, comprise the fifth level and,

6. Religious and transcendental ethics.

The first two levels can be thought probably to be common to all situations in healthcare, while levels three, five and six are widely divergent and influence the discussions of level four. These levels are never as perfectly clear in practice, but for a complete scheme of medical morality, moral agents are obliged to take positions at each level and resolve conflicts between subsequent relations. In this chapter, I will attempt to answer Pellegrino's three questions on responsibility in healthcare. For the purpose of this discussion, the focus will remain on the first three levels of moral agency. However, in chapter 4 the fifth level, i.e. the beliefs, values and principles derived by reason, will be discussed as part of the discussion on an ethics of responsibility. 
How is moral agency and responsibility allocated in the realm of collective decision-making in the healthcare setting?

Firstly, the concept of collective responsibility needs to be explained. Collective responsibility is inclusive of causal responsibility, i.e. a moral agent is responsible for a specific harm - he has caused the harm and therefore is responsible for it; and blameworthiness, which means that blame is ascribed to the moral agent for the specific harm done (Smiley, 2005). Collective responsibility is however not associated with the responsibility located in the free will of individuals. Collective responsibility is rather associated with groups or collectives, and the collective actions (or behaviours) of collectives. A collective or group could thus be seen as a moral agent by supporters of a collective responsibility theory.

Promoters of collective responsibility are usually criticized by methodological or normative individualists. The methodological individualist would not associate moral agency with groups at all, and the normative individualist would be convinced that collective responsibility violates the principles of individual responsibility and fairness. Collectivists would in return argue that collective responsibility can be valid where groups are seen as moral agents, and where collectives are believed to have group intentions, collective actions and group blameworthiness, which is ascribed coherently in a just way.

Kurt Baier (1972) distinguishes between personal (agent) responsibility and causal responsibility, where the latter involves inanimate objects and conditions, and the former could be interpreted in different ways, namely:

1. As a task or duty, i.e. a job description

2. As answerability, i.e. a duty to report

3. As accountability, i.e. when someone has executed an action

4. As culpability or blameworthiness, i.e. when someone is to be blamed for an action/omission

5. As liability, i.e. where such a person must suffer the consequences for a harmful action 
These distinctions make it easier to address the problem of attribution of responsibility, for instance in the healthcare team where the main task of the team is to ensure the patient's health and well-being. Culpability in this collective sense is a difficult concept, because who is to blame when the patient does not get well? And what happens to individual responsibility when an action performed by the collective leads to an unwell patient? The situation can become even more complex when issues such as the following are addressed:

1. When the harmful action or omission is unknown

2. When the act is known, but approved beforehand by all the members of the collective

3. When the act is not known or approved, but within the competence of the agent

French (1982) asks whether the identity of a group is dependent on its members. According to H.D. Lewis (1948) when he speaks of tribal primitives, a tribe's existence is independent of the specific members of the tribe and so is its moral responsibility, which is only collective. The tribal unit, i.e. the unit consisting of the tribal members, is more basic than the individual unit according to Lewis, and no responsibility is necessarily distributed to any member for a tribal action. He is therefore concerned that individual members may escape ascription of responsibility because of the fuzzy way in which collective responsibility is handled. French thinks however, that a tribalist theory is not a collective responsibility theory. The real dispute pace French is about what the basic moral unit is, because reduction of this unit is logically incoherent. He defines collective responsibility as "shared responsibility or distributive responsibility justified by group membership when the group is held morally responsible for something" (1982:69). This can only be true in groups he terms "aggregate collectives". Other groups, termed "conglomerate collectives" are responsible in themselves, because members have intentional agency and are part of the basic moral unit. Responsibility is therefore not reducible to individual ascriptions. French terms his theory "revised individualism", where moral responsibility can only be ascribed to basic moral units, and these basic units 
are redefined as non-natural concepts of moral personhood. Groups and organizations can therefore be included as moral units.

In an aggregate, the identity of the aggregate would be the sum of identities of all the members, described by Leibniz as "a state of being its constituent entities" (as cited in French, 1982). Every change in membership would entail a change in the identity of the aggregate. A particular aggregate is therefore not compatible with a change in membership. Two types of aggregates are found, namely an aggregate in a spatial and temporal sense where a group of people is brought together because of each individual's pursuit of his own ends. In such a group no decision-making procedure is in place, and there may or may not be a feeling of solidarity. This is sometimes described as a "random collection" (Held, 1970), but French (1982) and Bates (1971) are convinced it is not truly random as the word's etymology entails. It is only a group of people huddled together because of a certain characteristic that they share, and here the second type of aggregate surfaces, a group of individuals not bound by space and time but sharing a specific characteristic.

On the other hand, conglomerates' identity is not bound to the individual members' identities. The group's identity could not be exhausted by that of the individuals' either. A change in membership does not necessarily entail a change in identity. Conglomerates consist of human beings doing things for their own reasons and having their own behaviour, but because of a Corporate Internal Decision (CID) structure the intentional acts of the individuals become that of the conglomerate. Such a CID structure typically consists of a power structure, i.e. a flow chart or organogram, and decision/action recognition rules. The primary function of the structure is decision-making, ratification and an action process. The decisions and acts of various individuals can in such a way be incorporated into a conglomerate's decisions and acts. As French says, "the organizational chart provides what might be called the grammar of conglomerate decision-making. What I call internal recognition rules provide its logic" (1982:73). The recognition rules describe the process of making a decision to act for corporate reasons. It consists of a procedural aspect, where decisions are made at a certain level and ratified at the next level and a general policy that informs the decisions. This can be true in a hospital and in a 
government department and the process could be seen as analogous to the intentionality a human person has.

Taking French's views into account, the main controversy is then about collective responsibility as a concept, and the ascription of collective responsibility in practice. Can collective responsibility make sense in a non-distributive fashion, or can it only be applicable in an aggregate where every individual is only responsible for his specific contribution, and the sum of all the individual contributions makes up the collective? Sceptics are adamant that groups cannot have intentions, or cause harm, or be morally blameworthy.

For instance, if someone says 'the medical profession is responsible for the poor care of people living with HIV in South Africa', the primary decision must be whether the medical profession should be defined as an aggregate or a conglomerate. How would the medical profession be defined: all the medical practitioners at a specific time and place, or only the sum of all the individuals? Does it have an internal decision-making structure? Does it have ways of acting? Can acts be ascribed to it? What are the different levels of power? Are there different individuals with different duties? Only when these questions are answered in a systematic way, could collective decision-making and therefore collective responsibility be ascribed to a group or collective, in this case the medical profession in South Africa.

Other strategies used by collectivists to defend their position include the following (May \& Hoffman, 1991):

1. Moral responsibility is assigned to a group when a specific decision-making procedure is in place, for in such a case the group very closely resembles an individual with features of personhood including intentionality and the capacity to act. Corporative (or collective) intent may well differ from individual intent, and the action of a group can only take place through the actions of the individual members, but it is seen as part of a larger process where action and intention is best attributed to the whole group and not to individuals in particular. 
2. Common interests and needs can serve as a basis for group action where it leads to sufficient solidarity, with solidarity defined as (1991:3) "the sense that each member of a group has an interest in one another's interests and is motivated to act for the other's good." Such solidarity has the ability to focus a group's acts and intentions into a common will. A collective consciousness may develop whereby group members feel pride and shame for the group and thereby each other's actions. Collective responsibility can be assigned in such cases where there is sufficient cohesion for a solidary group to act in a similar way to a group with an internal decision-making structure.

3. A group can also be analyzed in terms of the benefits that the members receive because of their membership. These benefits may include increased social status and the recognition of expertise. By being a member of such a group, the member would also share in the costs involved when moral responsibility is assigned for consequences of group members' acts. A group member is therefore implored to prevent other members from acting harmfully, or at least dissociating himself from the harmful act if prevention is not possible.

The subsequent dilemma when a group is deemed morally, politically or legally responsible, is the distribution of responsibility within the group, i.e. how the responsibility would be shared. Two views currently dominate:

1. Where collective responsibility is merely an aggregate of the individual members' responsibility, i.e. the total responsibility is equal to the sum of all the individual responsibilities (French's 'aggregate collective'), and

2. Where collective responsibility is truly non-distributive, and only the group as a whole could be deemed responsible for a specific action or omission (French's 'conglomerate collective').

There is however, also a third view, characterised by group membership that determines the share of responsibility and a leader that could be held more responsible than a perpetrator for a specific harm. A further discussion of this view 
stretches beyond the scope of this thesis since an application of the view is not typically found in the healthcare setting.

To conclude the section on collective responsibility, French (1982) states that the medical profession is not a shield behind which individual practitioners can hide. If a group is defined as an aggregate, each individual would be distributively responsible for the group's action. If the group is defined as a conglomerate, the conglomerate would have a responsibility separate from each individual's responsibility, and the individual would carry both the conglomerate and her own responsibility.

How is this applicable to the healthcare setting?

The assumption is made that in the healthcare setting, as in any other collective setting, an individual could be held morally responsible on an individual basis, but also on a collective basis. Especially in the healthcare setting, more than elsewhere, individuals form part of different groups or collectives, and fulfill different roles as part of their profession. The distinction therefore needs to be made whether a healthcare professional, when acting, is ascribed responsibility on an individual or a collective level, or both. The possible attribution of blame could only be acceptable if and when such a distinction is clear.

And how is moral agency and responsibility allocated in a collective decision-making realm, such as the healthcare setting?

Firstly, it is important to realise that the medical professional acts as representative for the profession as well as the State (if employed by the State) and in that sense individual responsibility is transformed into collective responsibility because of the representation of a group and the subsequent role the medical professional assumes. This representation is ascriptive because the profession authorizes it, and it ascribes to the values and ethics of the profession. Here the concept of a social role (Bowie 1982) becomes an important reason to do away with only individual responsibility in healthcare. An individual would act in his private capacity, but in the setting of an institution as part of his social role.

An individual must however give consent to the role he agrees to act within. The three dimensions of a social role are (Downie 1982): 
1. The dimension of role-acceptance, where the individual accepts, refuses or resigns from his role. The individual's actions in his role are defined by the collective who authorizes him to act. He acts as a representative of the collective. In the healthcare setting, this would mean that a medical professional accepts his role as professional, and that his actions are defined by the medical profession which authorizes him to act. He acts as a representative of the medical profession.

2. The dimension of role-enactment, which depends on the individual's initiative according to the variation available in his role. The greater the variation, the more scope for moral judgment. For a doctor, the range or variety of skills and qualities endorses a large scope.

3. The morality of the role itself, where the nature of the role entails that it can lead to good or bad actions. Downie says "if a society is characterised in total abstraction from its members, this concept generally suggests the morality of the system of roles." (1982:51). Any medical professional could therefore still act badly, even as a professional. This could especially happen in a setting where the action of the medical profession is prescribed by a dictatorial or other discriminatory political regime.

Secondly, societal institutions are "images of ourselves as moral creatures" (Downie 1982:51). Society can thus be held responsible for societal roles, and what is true of society is also true of the medical profession as part of society. Through years of moral decisions, roles in the medical profession are moulded and influenced into what they are today. Recent changes in health care settings all over the world have also resulted in individuals not being solely responsible for their health (Newton, 1982). It is now the responsibility of society as well, and therefore the Government's obligation. The increased importance of non-medical factors influencing health systems, and the expensive technologies available to improve health overall, cannot be the responsibility of individuals alone. Social decisions need to be made and underlying these decisions are legitimate collective decision-making processes, such as should occur in a stable government.

Similar processes could also be prevalent in the healthcare professions. Newton (1982:13) defines a profession as: "an aggregate of persons similarly trained and somewhat similarly employed." What is then necessary for a healthcare profession 
to be deemed responsible, in the setting where the professional action could only be executed by a group? In a hospital for instance, would the responsibility of the patient not be included in the physician's (as individual), as well as that of the healthcare team (a collective) and the hospital (another collective)? The Hippocratic Oath should then be adapted to incorporate collective responsibility where needed, for the moral responsibility of a collective must become logical in this sense.

What about the responsibility of groups or collectives? How is this allocated within the healthcare setting?

For Wilmot (2000), a healthcare organization is accountable to the State and therefore has decreased freedom because of governmental control. It has less resemblance to a person than a private organization, because "a private corporation can do what it likes within the law rather like the individual in a liberal democratic society" (2000:142). The statement that an organization is sometimes part of something bigger, i.e. part of the governmental structure, does not make it impossible to have moral responsibility. Even with individual responsibility, a person is dependent on society for a sense of self and an idea of moral choices, and this practice is commonly held to be valid. A healthcare organisation could therefore be deemed collectively responsible, but in a lesser sense than an organisation independent of government.

When professionals are part of an organization, does the organization then become responsible for the individuals' action? In the healthcare setting the medical profession's standard of practice is usually regulated by a professional body such as the General Medical Council in the United Kingdom or the Health Professions Council in South Africa. In this sense corporate lines of decision-making co-exist with professional regulation. The professional performs a role which makes her accountable to the employer but also makes the employer accountable for the actions of the individual. If the professional does harm as part of her role, the employer is to blame unless the outcome can be determined in advance by the individual and predicted to be bad. Then she still is accountable to general morality. However, if the standard of practice is below par, the professional body could apply sanctions to the individual even if she acted within her role as defined by the 
employer. The professional therefore has at least two responsibilities due - one to her employer, and one to the professional body.

Newton (1982) develops three models according to which responsibility in the healthcare setting could be ascribed:

\section{Identification model}

The identification model is typical of a tribal sense of accountability, where the group and the individual members of the group are responsible for the acts of every member of the group because of her identification with the group. In tribal times, a tribe would be held responsible for an individual's action even post mortem. Although this theory has obvious theoretical flaws, the strength of the psychological bond between members should not be misjudged and is apparent in the emotions of pride and shame within the group or tribe. Feelings can however not be decisive in this matter when it is clearly unjust to attribute responsibility to a member who has not contributed to the harmful action in any way. The identification model would therefore seldom, if at all, be applicable in a modern society. Group responsibility should be dependent on the group's ability to influence the choices of the individual members.

\section{Participatory model}

This model makes each individual member responsible for the acts and omissions of the group and all the members of the group. This is typically the case in a conspiracy, where each member is guilty of an act performed by any member. The rationale behind the theory is that all members are responsible for the effects of activities they consent or engage in. The participatory model can especially be useful in "random collections" (Held, 1970), where any action would improve the outcome of the situation, and an action is therefore the responsibility of all of the members of the random collection. Each individual in such a scenario would be totally or conditionally responsible for the omission of the action. This model could be applied in a healthcare setting. 


\section{Authorization model}

In this model, conscious participation of the individual in each act is neither necessary nor expected. The individual authorizes by a single act, e.g. the signing of a contract, the creation of a new entity, with its own name and legal personality, which could be equitable to Hobbes' Leviathan (2008). This is characterised by the transformation of a group of individuals, or an aggregate (French, 1982) into a single being, or conglomerate, which adapts a set of rules and whose acts are deemed the acts of the collective because of a Corporate Internal Decision (CID) structure. Collective intention, decision and action are therefore possible for the conglomerate.

The conglomerate typically has a hierarchy of offices, a differentiation of tasks appointed to different members, and rule-governed procedures functioning as means to an end. Such a conglomerate can be a corporation or government body, or a hospital. A most important characteristic of use in the conglomerate is the job description. The job description defines what the person is at his specific place in the institution. It acts as a bridge between the bureaucratic background and its personnel. For a job-holder, his primary obligation is to do his job according to his job-description. This can and should however be qualified more in the sense of the way he does his job, if the job is really indicated, in his acceptance of the job, and the reasons for him not doing his job. There seems thus to develop a moral tension between the individual's responsibility to his own conscience and his collective responsibility to the entity.

\section{Are healthcare professions however organized enough to bear responsibility?}

Newton (1982) argues that healthcare professions accept the task of caring for the nation's health - the professions are therefore answerable, accountable and culpable. Certain negative inferences should however be clarified to ensure that these professions could indeed bear responsibility, viz:

1. If they are responsible, it does not necessarily mean they have a say about the way the responsibility is carried out or if it is indeed being carried out. They cannot expand healthcare facilities, or buy expensive equipment, or be accountable for distributive justice in society. Each healthcare worker can only be responsible for 
the quality of care at her specific position at a time and place - other decisions, for instance regarding equity in distribution, is part of the political process. The primary task of the healthcare worker is to improve healthcare, but this task is dependent on external and internal factors some of which may be historically handed down. Healthcare in its singularity is not enough, health education is imperative as well. Healthcare professions should therefore include a variety of other non-healthcare workers, like engineers, social workers and teachers.

2. The traditional employment positions of healthcare workers are according to minimal working conditions where the acceptance of responsibility is not part of these conditions.

3. The healthcare professions are known to be disorganized from within, entailing disagreement among themselves and no notion of being accountable as a group (Newton 1982:18-19)

Can such a profession therefore accept moral responsibility and exercise the right to it?

Traditional views (Lewis, 1948) have declared any collection of people, whether an aggregate or a conglomerate, amoral, but French (1982) and DeGeorge (1982) have shown that collective responsibility is indeed not only a theoretical concept but can be valid in the hospital setting. Newton (1982:20) agrees with French and DeGeorge, stating:

"There seems no reason why an association of moral persons, authorized by a set of rules to act, in some situations, as a corporation, with a developed CID structure to determine what intentions and decisions shall count as the intentions and decisions of that corporation, cannot assume and accept moral responsibility for all its undertakings."

Such a conglomerate would not be able to feel pride or shame regarding its actions, but this is not significant. It is however, essential that the possibility of collective responsibility in healthcare is real, keeping in mind that the concepts of choice, decision-making and action are explained differently in terms of the collective, and that a direct comparison between individual responsibility and collective responsibility may not be possible. 


\section{How is each member's moral agency influenced by the collective?}

In any profession, skills and knowledge are used to protect the health and safety of the public and to cause no harm. Since there are many professionals within organizations or government departments, a collective effort to reach these goals usually leads to some measure of collective responsibility among these professionals (Flores \& Johnson, 1983). The question arises whether these professionals are also responsible as individuals, and if not, how to ensure that mistakes would not be repeated in the future, i.e. ensure that behavioural changes ensue as a consequence of harmful decisions and actions taken on an individual level. Flores and Johnson (1982) see no conceptual difficulty to assume that the ascription of collective responsibility is justified, since a collective's activities can lead to moral consequences, and collective responsibility is commonly assigned in society. The struggle lies in the apportionment of responsibility to individuals who form part of the collective. However, ascriptions of collective responsibility also need to be validated against the known characteristics of an object of responsibility, i.e. intention, choice, knowledge and possible agency (Corlett 2001).

According to H.D. Lewis (1948) however, no-one can be responsible for the conduct of another - responsibility in its essence belongs to the individual. If this version of the concept of responsibility seems to cause too many difficulties, Lewis argues against moving towards the "barbarous notion of collective responsibility" (1948:3), but rather to give up on the notion of moral accountability altogether. For, he writes, if we believe that moral responsibility should be shared, it becomes too difficult to draw moral distinctions between one action and another. We would therefore be directly implicated in each other's actions, i.e. praised or blamed for another's actions.

However, in a corporation no individual has the ultimate or overall responsibility. Individuals usually act in roles they assume according to their job descriptions, acting as representatives of the organisation. According to Walsh (1970), when an individual is acting in a role it can be seen as a non-voluntary act, in contrast to Aristotle's (1955) voluntary acts (as necessary condition for individual responsibility). 
Since a professional's role is dictated by the rules of the organization, the standard Aristotelian criteria of being free and being himself cannot be fulfilled. In an organization, an individual can be seen not to be free in the sense that he is acting according to the role the organization has determined; he is also representing the organization and acting according to the organization's ends, which diminishes his individuality. Flores and Johnson (1983:541) state:

\footnotetext{
"The actions or decisions of any particular person apparently could or would be made by any individual in the same role or position. Insofar as so little of a person' individuality bears on a given decision, the individual cannot be considered himself when he acts."
}

But they counter by using the following arguments:

1. An individual is still free by deliberation to choose membership of an organization and can voluntarily assume the role specified. Usually such an individual is not born into the role and not coerced into it either. She can resign or stay on according to her circumstances, but her duties should never include contributions to immoral acts. This argument does however produce some problems in the healthcare setting. Before a doctor starts his career as a medical professional, an Oath is signed to protect his patients at all times. Any practising healthcare professional can only practice under the condition of membership to a health professions council. Such a council would not in normal circumstances coerce the professional to do immoral acts, but she is still bound to follow her Oath and the council's guidelines if she wants to practise as a healthcare professional.

2. She will gain personal benefit from the organization's action and therefore would not be acting wholly impersonally, but for her self and to secure her personal ends. Her choosing to act decisive is of cardinal importance here; she is not forced to make her decisions. This argument could be of importance in the healthcare setting, where the health professions council usually acts as the voice of the professionals in high-level governmental issues. The council is usually able to influence decisions and policies according to its members' opinions.

3. She can also add her own moral qualities and personal values to the role, but this may of course vary according to the organization's rules. Her role does not undermine her autonomy, and she is still responsible for her own behaviour. This of course becomes increasingly difficult if the organization one forms part of, is also one's employer. In such a situation, one would maybe opt to adapt one's own 
values towards those of the organization, which is an unfortunate consequence of dependency.

The choices of an individual in a professional role therefore could include fulfillment of the role according to the organization's rule and the code of ethics of the profession, refusal to fulfill the role, or an attempt to redefine the role. The role alone does not absolve the professional from her duties as individual; she is still responsible for the outcomes of her individual actions and behaviour. Collective responsibility therefore does not shield or insulate individual members from being culpable, liable or accountable.

However, not all members always contribute to the collective action. According to Flores and Johnson (1983), three conditions must be met for an individual to be part of the collective action:

1. The individual must be autonomous to some extent although the extent of autonomy can vary by definition of the role. This means that the minimal autonomy of the individual must be further qualified.

2. The individual must causally contribute to the collective action, which is again a difficult concept because any individual at any time can contribute to numerous collective actions - which to choose, and how far back to choose from? It can easily become an account of infinite regression.

3. The individual's role must incorporate the duty to protect public health. In this sense conflict of duty may arise if a clear hierarchy of duties are not predetermined. The individual's duties towards himself, his family, his employer/the State and to the general society could be contrasting and therefore conflicting. It becomes easier when a role is defined and regulated by an internal code of ethics, but the conflict of duty remains a complex issue. It is of specific importance when a physician decides to act against a protocol or guideline for the sake of his patient.

The ascription and acceptance of roles within the healthcare profession therefore plays an important role in the way that an individual's agency is influenced by the collective. Autonomy of the individual remains a necessary condition even for the ascription of collective responsibility, and the individual needs to take part in the collective action. Any such an action should also contribute to public health. 
Each individual healthcare professional could struggle with role conflict, for example a nurse would be conflicted between the moral principles of the individual rights of the patients and the utilitarian goal of the institution (Murphy, 1978), but when one is acting in a role, one is not only acting as an individual but bound to operate within the framework (Downie, 1982). Since healthcare is humanly created, it has a purpose and a function. The means to achieve this function is stipulated in its general rules and expectations. Responsibilities of an individual's role would be dependent on the type of job the role entails, and would have specified rules and expectations.

Each member of the healthcare team would therefore have to adapt to the specified rules and expectations of the type of job that she does. This could however, still be possible within a framework of individual autonomy, but the individual's autonomy would have to be clarified within the specific organisation. Different organisations may have different ways of expecting individuals to enact individual autonomy.

\section{To whom is moral responsibility primarily due?}

From a role morality point of view which specifies moral duties and obligations, many ethical dilemmas would subsequently disappear. For instance, if a doctor is conflicted between his patient's confidentiality and the public good (for the patient has an extremely contagious, but stigmatised disease), the obligation to silence overrides the obligation to promote justice because of his role obligation. "His role as physician excludes the public good from consideration", Bowie states (1982:59). Role obligations are however always prima facie and can be overruled by universal moral norms.

These obligations thus have to face two criticisms, firstly from universal norms as mentioned above and secondly from internal contradictions (as in the case of a nurse having dual responsibility towards her patient and towards the hospital). Because of the business-like environment of many newer hospitals, efficiency becomes an important value for a hospital to have. If the primary goal is still to care for and treat the patient obvious internal conflicts can be expected. These internal conflicts are constantly changing and the "weighing and shifting of goals" (1982:62) causes 
continuous ambiguity. If a physician treats a nurse patronisingly not as a colleague, but as an inferior, universal norms such as a defense against a master-slave relationship and sexism should cause role obligations to be revised. The universal norms are however fundamental concepts, and no weighing and shifting should be expected.

It still remains important to realise that conflict between different groups to whom moral responsibility is due, would arise in the medical fraternity. It simplifies the matter to state that according to role responsibility, this conflict is easily managed. What should be kept in mind is that individuals in the healthcare setting deal with important issues such as severe disease, life-threatening disease and death. These issues cannot be brushed off easily by using a theoretical framework. In practice, the resolution of conflict will depend on the specific situation, and each medical professional will have to use her skills as individual, taking responsibility for the healing relationship, as well as her own moral beliefs and values, to interpret the conflict to the best of her abilities. She will also have to take into account the background beliefs of the clients involved in the conflict situation, and their religious and transcendental ethics. Lastly, she will have to be accountable to the collectives she belongs to, i.e. the hospital and the medical profession.

To say then, that role responsibility is the answer to the resolution of conflict in a healthcare setting, may be a good suggestion, especially when role responsibility could be used as a framework from which decisions are being planned. It does, however, in practice, remain difficult to resolve conflict. A conflict situation should be judged on its own terms and analysed accordingly with whichever means the healthcare professional has available and is skilled in using. 


\section{Conclusion}

Collective responsibility seems to be sensible in a conglomerate where an internal decision-making structure ensures that decisions and acts analogous to individual decisions and acts are promulgated. To say that collective responsibility is a "barbarous notion" (Lewis, 1948), I think, misses the point. When collective responsibility is seen solely as a mechanism behind which individuals hide, with the consequence that no responsibility is accepted for any action of individual or collective nature, of course the concept cannot be endorsed. However, sometimes in some collectives, responsibility for an action entails more than only the sum of the individuals responsible for delivering a physical action. In such a case, collective responsibility may be ascribed on top of each individual's responsibility for his own action. A surgeon would therefore be responsible for the cuts he made, as well as the overall team effort in saving a patient's life in the emergency room together with his team mates. Accolade would be afforded to him for his surgical skill, but to the team for saving a life. Of course it is not possible for a collective of any sort to act on its own, or to think exactly in the way an individual thinks, but the analogy of an internal decision-making structure seems to fit the considerations for collective responsibility.

Whether ultimate moral responsibility exists or not, is of no significance for a medical professional. Because of the role such a professional agrees to, he is responsible as an individual for his patients in a physician-patient relationship ensuring confidentiality. He is also responsible as part of the profession to abide by the ethical guidelines put in place by the professional board. He may also be responsible as part of a surgical team or an emergency medical team, and he may be responsible for decision-making as part of a hospital's decision-making structure. When a medical professional disregards any of these responsibilities, he becomes guilty of negligence. This is not only a moral concern, but also a legal concern.

The crisis however, arises when internal conflict exists because of different responsibilities that direct him in opposite ways of action. As an individual, he must then still deliberate, choose and act in the way that seems morally acceptable. Such 
decisions may however cause difficulty in his career path, his personal life or his status as a professional. These issues are crucial and will be discussed in more depth in the last chapter when dr Thys von Mollendorff's case study is investigated. 
On what condition is responsibility possible? On the condition that the Good no longer be a transcendental objective, a relation between objective things, but the relation to the other, a response to the other; an experience of personal goodness and a movement of intention.

Jacques Derrida 


\section{Chapter 3 - An Ethics of Responsibility}

\section{Introduction}

Responsibility must also be defined in current contexts. Moving into post-modern times, philosophers like Bauman, Levinas and Jonas have written about the interpretation of the concept of responsibility within a post-modern world. This chapter addresses the third question surrounding responsibility - the question of an ethics of responsibility.

According to Bauman (1992), postmodernity means "the exhilarating freedom to pursue anything and the mind-boggling uncertainty as to what is worth pursuing and in the name of what one should pursue it". Postmodernity is not however, as Chris Norris states "merely the most extreme (or as some would say, most consistent and consequent) version of this desire to have done with all truth-claims beyond what is precisely and contingently "good in the way of belief'" (Crawford, 1998). It is also not a "substitution of aesthetics for ethics" or the "demise of the ethical" (Bauman 1993). The ideas and concepts of postmodernity rather engage in trying to leave behind modern ways of finding solutions for ethical problems. The modern error therefore, according to the postmodern theory, does not lie in the principle or ethical code itself but in the way that a moral decision is reached. In the postmodern era ethics have thus not disappeared, but are dealt with in a new way where the choice of action becomes utterly important, where the responsibility for one's own choice and the consequences thereof is priority, and the blind following of a rule, tradition, principle or code becomes problematic.

\section{Responsibility in context}

Hans Jonas (1995) writes that previous theories of ethics had certain premises in common, namely that the human condition was a given, not changing - a static object when regarding ethics. The human good was therefore easily determinable, and the range of human action was narrow and well defined. This is however no longer the case, because the nature of human action has changed with the advance 
of technology. Human nature and action has now changed so significantly that a new ethics is needed and is indeed emerging.

In previous civilisations, Nature was seen as essentially immutable, untouchable by human action. Man was king of his castle, ruler of his domain, the city, where his control was absolute but small, and his nature prevailed. Traditional ethics was formed within this intra-human framework, where Nature was not brought into account - she was above this framework, and not touched by it. Previous dealings with technology (all except medical technology) were ethically neutral, and no action on a non-human object was deemed ethically significant. Ethics was grounded in anthropocentrism, where man's essence was considered a constant. Good and evil were never remote - consequences were close to actions that caused them, in time and in space.

The traditional ethical maxims were developed in a setting where the agent and the 'Other' shared the same present. The knowledge required to act according to these maxims was readily available to any man of good will - such a man did not have to be a scientist or an expert. This knowledge was non-theoretical, for the present. Good and bad were decided upon within the context of short term effects - no long term, unexpected effects were included in any moral discussions.

But now, modern technology has brought forth new ethical dimensions that should be reckoned with. Nature is now vulnerable, to such an extent that man has become responsible for the whole of the biosphere. Ethical decisions are cumulative and not bound by space and time anymore. Knowledge takes on a new role - to have knowledge has become a duty, but predictive knowledge lags far behind technological knowledge and therefore a new conception of duties and rights are needed. The nature of ethics is not anthropocentric alone anymore - extrahuman Nature now has a moral claim on human beings, not only for our own sake, but for its sake as well. We therefore need to extend our recognition of 'ends in themselves' to reach beyond the scope of human beings alone. 
We need to accept the call of duty: whether we, as agents, would be able to enjoy the good or not, or whether we live to see whether our goal is achieved or not. Thus is the paradox of morality:

“... the self forgets itself over the pursuit of the object, so that a higher self might come into being." (Jonas 2005:85)

We should do good for its own sake, without morality becoming its own goal. The content of action, and not its form, becomes priority in this technological advanced age.

Van Niekerk (2008:1) defines the concept of responsibility as follows:

“... to be able to be held accountable for whatever decisions is taken on the basis of the assumption that reasons can be provided, that they have been thought through, even though they might be fallible."

This concept of responsibility endorses a no-universal rule policy, which is trademarked by inconsistency. Responsibility must be accepted for all actions, and moral responsibility does not entail rules, codes or laws behind which an agent could hide successfully.

An ethics of responsibility is:

“... an approach where, on the basis of recognition of the moral ambivalence associated with most of the phenomena in the social world, the main task of moral judgment is not deemed consistency within a single paradigm, but the acceptance of responsibility for whatever line of action is recommended." (Van Niekerk 2002:40)

But to whom are we responsible? Levinas develops the idea of the "Other" which is taken up by Bauman. We are according to Bauman (1995), existentially moral beings responsible for the Other. To be moral is to have the freedom to choose between good and evil which entails an obvious situation of ambivalence. The choice always means the assumption of responsibility and for this reason bears the character of a moral act (Bauman, 1992). Facing this responsibility is the meaning of being moral. It has a life of continuous uncertainty as consequence and leads to loneliness - a moral being is alone in her choice. 
For Levinas, morality is non-reducible. The starting point of morality is 'being-forthe-other'. Moral responsibility is fundamental, it does not have causes or determining factors. By being, we are responsible for the Other. Van Niekerk (2008) highlights four key elements of responsibility:

- We have an obligation to accept our moral responsibility and in doing so, discover the truth.

- Responsibility deals with different kinds of ethical approaches, and moves beyond the realm of relativity.

- It also moves across disciplines, i.e. is multi-disciplinary.

- It does not only include technical and economical values, but also environmental, social and cultural values.

To take responsibility does not mean to act without making mistakes, but to act in an accountable way. Reasons for actions must be supplied at all times, and any moral agent must be open to criticism if he fails, which may of course happen!

Derrida (1995) also foresees an aporia in the responsibility of an individual - moral responsibility needs to continue in a postmodern individual, but this responsibility entails unfortunate loneliness. In making a decision, one stands alone and only one's own subjective rationale can be accountable for the consequence of a decision. Therein lays the aporia: that in being silent and secret, unaccountability towards the other members of the moral community appears. He says that "responsibility demands on the one hand an accounting... with respect to the general... and on the other hand, uniqueness... silence and secrecy."

In the pre-modern world, a moral being had only to repent a wrongdoing to become moral - it was morality ex post facto cure. In the modern world, the ethical code was designed precisely to prevent sin or wrongdoing. A moral being thus had an a priori knowledge of what is right. In that world to be good meant to obey the rules laid down by the supra-individual authority. The good and the right were uncontroversial, and easily recognisable. This resulted in the severance of the relationship between human choice and the moral dimension leading to a shift of ethical responsibility to supra-individual agencies. When this responsibility became a 
set of obligations, the agony of choice for the individual disappeared and she could breathe again not having to face the consequence of a personal wrong decision. Personal responsibility and the possibility of sin therefore became non-existent if an individual followed the rules of the pre-modern world.

The Modern conception of universal moral principles to guide our moral lives or the morality of society, and without which morality will collapse, dissipated with the advent of post-modernism. However, we are still in a transitional phase, moving from one paradigm to the next, and the concept of contingency or uncertainty introduced in the postmodern realm, is a horrific aspect of moral life we struggle to face. This so-called horror vacui exonerates the potential danger of the postmodern condition (Bauman, 1992). The void was left by the ineffective moral supervision of the pre-modern Church and ought according to Modernity, to be filled with a rational set of rules (Bauman, 1993). Modernity tried with a continuous effort to fill this vacuum of fear. It believed that the vacuum can indeed be filled and it had the ultimate purpose of succeeding to fill it. In the postmodern era however, the realisation that the void cannot be filled was made and the purposeful effort stopped though no new answer to the problem of fear was presented.

According to Bauman (1993) there are a few trademarks of the moral condition from the postmodern perspective:

1. All humans are morally ambivalent; that given the primary structure of human togetherness, a non-ambivalent morality is an existential impossibility. It follows that moral conduct cannot be guaranteed.

2. Moral phenomena are also inherently non-rational. They are only valid if they precede the consideration for purpose and the calculation of gains and losses.

3. Morality is incurably aporetic with few choices being unambiguously good. The majority of moral choices are made between contradictory impulses. Uncertainty is bound to accompany the condition of the moral self forever.

4. Morality is also not universalizable. This does not, according to Bauman, necessarily endorse moral relativism. 
5. From the perspective of rational order, morality is bound to remain irrational where autonomy of the moral self is a scandal.

6. Given the ambiguous impact of societal efforts at ethical legislation, one must assume that moral responsibility - being for the Other before one can be with the Other - is the first reality of the self, but morality cannot justify itself.

7. The postmodern perspective on moral phenomena does not reveal the relativism of morality, but rather the emancipation of the autonomous moral self and the vindication of its moral responsibility.

Bauman (1993) emphasizes that 'the kind of understanding of the moral self's condition which the postmodern vantage point allows is unlikely to make moral life easier. The most it can dream of is making it a bit more moral'.

Modernity left individuals with an ethical choice and individual moral responsibility which were subjected to the discourse of an objective truth at a supra-individual level. The individual is therefore left with ethical confusion: she has her own problems and responsibilities, combined with the lack of clarity of moral choices, and the knowledge that these challenges cannot be resolved completely. The paradox lies in the restoration of moral choice and responsibility to the individual without universal guidelines. The individual is faced with a moral responsibility and the loneliness of moral choice, where her own subjective morality is the only authority and any ethical code becomes relative. It is important to note that the code becomes relative, and not the ethics. The limits of her auto-responsibility are not well defined.

This paradox leads to a practical dilemma: if a person acts on her convictions, she would want those convictions to be accepted universally. This is not possible with the postmodern tolerance where restrictions on freedom are controversial, and subsequently can lead to indifference on the individual's side, where the consistent rejection of heteronomy and monologic stance leads to moral relativism. It therefore becomes an existential insecurity, where a 'global mean between 
colonizing temptations and the selfishness of tribal self-closure' (Bauman, 1992) must be found.

Derrida (1992) states that justice needs to be distinguished from the law; that every decision must be based on the law, but that the law itself must be re-judged with every decision. He says:

\footnotetext{
"...for a decision to be just and responsible, it must, in its proper moment if there is one, be both regulated and without regulation: it must conserve the law and also destroy it or suspend it long enough to have to reinvent it in each case, rejustify it, at least reinvent it in the reaffirmation and the new and free confirmation of its principle. Each case is other, each decision is different and requires an absolutely unique interpretation, which no existing, coded rule can or ought to guarantee absolutely."
}

It follows that if a decision is only based on law or rule or principle, it cannot be just. Every decision needs re-interpretation of the law, so a decision is never completely according to the rule, but also never completely without the rule. Herein lies a paradox: a decision made in present time can never be just, only legal. This observation also applies to ethical rules or principles and is known as Derrida's first aporia of deconstruction, or 'the épochè of the rule'.

His second aporia, 'the ghost of the undecidable' states that the moment between the 'ordeal of the undecidable' and the making of the decision when a new rule is immediately formed, is the only just moment. A just decision is therefore a ghost, an invisible something in between, which can be interpreted and sensed, but not reached or attained. He quotes Kierkegaard saying: "The instant of a decision is madness."

Another concept Derrida introduced which was further explored by Cornell (Cilliers, 1998 ) interpreted the flow of time in a system as a notion called I - the future as well as the present have to be considered when making a moral decision, even if this leads to an aporetic situation because we do not know what the future entails! Since the future is influenced by what happens today (Van Niekerk, 2008), whether it is determined or not, some things can be predicted and a definite connection with the past exists. 
To use universal principles, is to deny the complexity of the system we live in; to say 'everything goes', is to evade our moral responsibility. Cilliers (1998) reformulates Derrida and Cornell's argument and states that we have to follow rules as if they were universal rules, with the preset condition that these rules can be changed or even discarded when deemed necessary. Each time a rule is used, renewed appraisal of such a rule must occur. Ethical behaviour therefore means the responsible use of rules. He further states that to make a responsible judgment would involve the following aspects: (1) respecting otherness and difference as values in themselves, (2) gathering as much information on the issue as possible, notwithstanding the fact that it is impossible to gather all information, (3) considering as many of the possible consequences of the judgment, notwithstanding the fact that it is impossible to consider all the consequences, and (4) making sure that it is possible to revise the judgment as soon as it becomes clear that it has flaws, whether it be under specific circumstances, or in general.

An ethics of responsibility means that a decision must be made to move forward (Van Niekerk, 2008). Any decision and subsequent action always is at risk of failure, but not taking any action may lead to an even bigger disaster. Responsibility does not deal with certainty, and one is not guaranteed correct moral behaviour, only responsible moral behaviour. One needs to consider the consequences of one's actions, but should also endorse the importance of moral intuitions and collective wisdom. Van Niekerk is of the opinion that Aristotle's intellectual virtues, especially his concept of prudence or practical wisdom, are of cardinal importance for an inclusive responsibility theory. It teaches us how to act in everyday situations and thus how to influence policy forming. This practical wisdom is not fixed, it includes both means and ends, and it ensures that guidelines or codes can be applied to any situation at hand through the process of deliberation, "a dialectic movement between action guide and the requirements of the practical situation, as well as the possible consequences of the action" (Van Niekerk, 2008:7). 


\section{Conclusion}

In my opinion, an ethics of responsibility therefore means that one can choose and has to choose when a choice lies in front of you. One must choose deliberately, prudently, knowledgeably, and then act according to your choice. One must deliberate all possible consequences of your choice, and be willing to accept these consequences. One must be accountable not only for your choice, but for all the possible deliberated consequences of your choice, and even for consequences you could not foresee. To be accountable in such a manner means that you as an individual are embracing an ethics of responsibility.

In the last chapter, the practical application of an ethics of responsibility will be discussed in further detail. 
If one sees a five-year-old raped girl's torn body and the plea for help in her eyes, you do everything that any doctor should do. You help her with all the knowledge and means at your disposal.

Dr Thys von Mollendorff 


\section{Chapter 4 - Case Study}

Dr Thys von Mollendorff was called to operate on a four year old girl one evening in 2000. The small girl was gang-raped, her genitals cut. He took her to the operating room where he did the necessary procedures to sustain her life. A few months later he did reconstructive surgery with the hope of sustaining some of her dignity. The experience lead to his decision to allow a non-governmental organisation, the Greater Nelspruit Rape Intervention Project (GRIP), to provide free counseling and antiretroviral treatment to a growing number of rape victims at his hospital.

The decision cost him his job and led to a national debate. With the government not yet endorsing the use of antiretrovirals to prevent rape victims from contracting HIV/AIDS, should health professionals in the public sector follow the government or the Hippocratic Oath? He was faced with a dual loyalty dilemma, torn between allegiance to the political head of the Department of Health and his obligation towards his patients.

\section{Case History}

In 1997, non-governmental organisations lobbied with the Department of Health to develop a program to prevent mother-to-child transmission of HIV. Initially, the Health Ministry supported these efforts. By the end of 1999 however, South African government officials had begun to express concern about the safety of antiretroviral drugs. In a 1999 speech, President Thabo Mbeki questioned the safety of AZT. Two weeks later, Health Minister Manto Tshabalala-Msimang told the National Assembly that "scientists say that not enough is yet known about the effects of AZT". At the time, the HIV infection incidence had increased from $26 \%$ to $30 \%$ over a period of three years, measured at antenatal clinics in Mpumalanga (Von Mollendorff, 2009). The local Victim Empowerment Committee (VEC) in the Nelspruit area visited the Rob Ferreira Hospital where Thys von Mollendorff was superintendent, investigating whether a care room for rape survivors had been established at the hospital as was written in the National Policy Guidelines for the Victims of Sexual Offences. By the 
end of 1999, an unused office was identified in the outpatients department and refurbished to become such a care room.

On February 16, 2000 a Rape Indaba was held in Nelspruit, attended by different government departments, the local VEC and non-governmental organisations (NGOs). By the end of the meeting, a group of volunteers had formed a cocoordinating committee called the Greater Nelspruit Rape Intervention Program (GRIP) which functioned as a NGO with a constitution and fund-raising programs. In March 2000 GRIP started emergency debriefing and counseling services at the hospital. GRIP was granted access to the hospital similarly to other NGOs like FAMSA and LoveLife. The care room was officially opened on April 17. For any rape victim, GRIP would provide emergency counseling and a courtesy pack free of charge. Such a patient would then be referred for in-depth counseling, but no antiretrovirals were available to prevent the transmission of HIV.

At the same time, government officials began to question the causal link between HIV and AIDS when Mbeki started to solicit the opinions of AIDS 'denialists', a small group of scientists and activists who believe that AIDS in Africa is not caused by HIV but by poverty, poverty-related illnesses and drugs used to treat HIV. In May 2000, Mbeki's questions about the causes of AIDS gained influence in the African National Congress (ANC) and began to influence health policy at national and provincial level. In August 2000, the Health Minister and the Executive Council made the decision to provide the antiretroviral drug nevirapine at a number of pilot sites only. This decision ignored the head of the national AIDS office's recommendation to provide nevirapine to all HIV-positive pregnant women. Back in Nelspruit, GRIP felt a moral inclination to not only provide counseling services to rape victims, but also prevent HIV transmission by treating with antiretrovirals. The National Policy Guidelines then allowed for rape victims to be referred for voluntary counseling and testing (VCT), and also for healthcare services to provide the necessary treatment. GRIP started to keep post-exposure antiretroviral starter packs in stock. This meant that victims were guaranteed antiretroviral treatment for the immediate time period after the incident up to a period of three days, where after they could be referred to a pharmacy to get a month's supply of treatment if they were confirmed HIV negative. 
This treatment was also free of charge to the patient and paid for by GRIP. They were therefore ensuring best possible care for the victims, which included follow-up visits to rule out side effects of the treatment, and repeated HIV-tests. At the time the Department of Health did not have counselors or field workers to deliver this type of service.

In September 2000 an official from the national Department of Health phoned then provincial health MEC Sibongile Manana to enquire about the care room and provision of antiretrovirals. She was not aware of its existence up till then, and subsequently criticized GRIP for providing ART to rape survivors, reportedly accusing GRIP and Von Mollendorff of "poisoning black people" and undermining national government policy. She banned the use of ART, tried to evict GRIP from the hospital grounds and charged the senior management with misconduct. On March 1, 2001 the charges were withdrawn allowing GRIP back in for counseling services, but not ART. These charges were reinstated and withdrawn again four times thereafter. Although the National Policy on Sexual Offences stated that emergency treatment for rape victims to prevent HIV transmission should be available, the Mpumalanga Department of Health did not reply to several letters from the VEC requesting ART for the rape victims. The hospital management was also not given any directives about ART in general. A proposed meeting between Manana and some superintendents from the local hospitals failed, and the hospitals did not receive any guidance from the provincial office.

The government of South Africa was severely criticised by the South African Medical Association (SAMA) in 2001 for a lack in direction in the roll-out of an antiretroviral program. SAMA called on government to provide antiretroviral treatment (ART) to South Africans in the public sector. At the time, dr Kgosi Letlape, chairperson of SAMA, claimed South Africa was the only country in the world not having such a program. Dr Anant Chetty, then Chairperson of SAMA's Human Rights, Ethics and Law Committee, emphasized that doctors should not be afraid to prescribe antiretroviral drugs, and said, "Doctors' ethical and moral rights are protected in our constitution, their clinical independence is fully supported by the Health Professions Council of South Africa (HPCSA) and internationally by world health organizations" 
(World Medical Journal 2004). After an unsuccessful meeting with Health Minister Manto Tshabalala-Msimang, SAMA continued its efforts to facilitate treatment for people living with HIV/AIDS, irrespective of the government's position of not providing ART. Doctors' clinical independence came under fire with the dismissal of dr Thys von Mollendorff. Letlape referred to the dismissal as an example in which doctors' responsibility to their patients was severely disrupted, which was in direct contrast with the rights of the individual, which are entrenched in the constitution. He also referred to the $38^{\text {th }}$ World Medical Assembly (WMA) in 1986 when the WMA unambiguously denounced political interference in health care delivery and said that medical practitioners have an ethical duty to act in the best interest of their HIVpatients, who form an exceptionally vulnerable group in South Africa. SAMA subsequently adapted a set of WMA guidelines "HIV Human Rights and Ethical Guidelines" as well as a document on "Doctors and Patients' Rights and Responsibilities" to the South African context. These documents translate the human rights found in the South African Constitution into real-life situations affecting doctors and patients. It also includes responsibilities or duties. The ART program was only launched a year later by SAMA at GF Jooste Hospital in the Western Cape.

In August 2001, a coalition including the Treatment Action Campaign (TAC) sued the government for not providing antiretroviral treatment (ART) to all HIV-positive women in the public sector to prevent mother-to-child HIV transmission. On September 1, 2001 NEHAWU took the senior management of Rob Ferreira hospital hostage, demanding a senior medical officer who supported GRIP and ART, saying "bring the doctor, we want to kill him!" This doctor was chased from the hospital with sticks. It was suspected that Manana made use of her influence at the union to undermine GRIP and the senior management. On October 13, 2001 Manana said that no outside initiative would be tolerated, and she demoted a district manager from the Ehlanzeni district for being involved in the dispensation of antiretrovirals.

On November 6 2001, Manana suspended Von Mollendorff, charging him with gross misconduct and insubordination for allowing GRIP to dispense drugs in a manner the provincial Department of Health considered a violation of national and provincial 
policy. He was subjected to a disciplinary hearing conducted in the office of Premier Ndaweni Mahlangu. Two weeks later, he was found guilty of insubordination. On February 22 , he was told to meet a department official at a local intersection where he was handed a letter stating that he had been fired. The World Medical Association said on March 8 that "it is unacceptable that patients are being denied treatment for solely political or economic reasons" (Baleta 2002). Von Mollendorff said: "I am frustrated because there is a serious shortage of state doctors. I feel ethically bound to serve patients and I cannot turn my back on life-saving drugs" (Baleta 2002). Later on Amnesty International urged the Minister to stop the harassment of health care professionals in Mpumalanga and to uphold professional ethics.

In December 2001, after the Pretoria High Court ruled that the government's refusal to provide ART violated the constitution, Tshabalala-Msimang announced she would seek leave to appeal this decision in the Constitutional Court.

On Friday, 22 February 2002 dr Thys von Mollendorff was dismissed from his position as superintendent of Rob Ferreira Hospital in Nelspruit (Altenroxel 2002). Permission for GRIP to work there was requested from the Mpumalanga Health Department, and regular progress reports were submitted to the province for several months before Manana appeared to have a change of heart. She accused GRIP of being "illegal squatters" and unlawfully handing out scheduled drugs. "The health and lives of our poor black people were placed under serious threat by this organisation, which claims to have their interests at heart," said Manana. When her attempts to evict GRIP failed, she turned her attention to Von Mollendorff.

In a newsletter published by TAC (Treatment Action Campaign) on $18^{\text {th }}$ March 2002, and the Indian Journal of Medical Ethics (2002), a statement was made by a group of academics stating that "Physicians must have the professional freedom to care for their patients without interference. The exercise of the physician's professional judgment and discretion in making clinical and ethical decisions in the care and treatment of patients must be preserved and protected. Physicians must have the 
professional independence to represent and defend the health needs of patients against all who would deny or restrict needed care for those who are sick or injured."

Von Mollendorff subsequently appealed the decision, but lost the appeal on 17 May 2002 (Dispatch 2002) when neither he nor his attorney was informed about the date of the appeal (Amnesty International 2003). He took the case to the labour court (SABC News 2002), but Manana's influence meant that the Labour Court ruled no urgency in the matter. It was commented by Mark Lowe MP in Parliament (2002) that "the government still refuses to acknowledge that HIV causes AIDS, and stand by while its Mpumalanga Health MEC fires Von Mollendorff for allowing the provision of free antiretroviral drugs to rape survivors, which is not just bizarre and surreal, but, frankly, a crime against humanity". Later that year Von Mollendorff received a leadership award in October when it was commented by former Mpumalanga premier Matthews Phosa that "Von Mollendorff had shown that working for the greater good sometimes demanded personal sacrifice" (FIN24: Empowering Financial Decisions 2002).

Human rights law experts from the University of the Witwatersrand commented that the axing of Dr Von Mollendorff was ethically indefensible (SAPA 2002). According to them, the MEC should have reconsidered her actions in the light of doctors' universally recognised ethical obligations. The university experts said political interference in health care delivery was unambiguously denounced by the World Medical Association in a declaration as far back as 1986. “Dr Von Mollendorff acted within the letter and spirit of this declaration. The victimising for having defended the highest principles of this profession was unjust in terms of humane ethical standards," they said.

A statement by the South African Academy of Family Practice (Treatment Action Campaign Newsletter 2002) expressed its disappointment with Dr Von Mollendorff's dismissal. "Dr Von Mollendorff was carrying out what is regarded as an ethical duty for a medical practitioner to put the well-being of his patients as his primary professional duty. Not allowing rape survivors access to counseling and antiretroviral drugs where appropriate does not constitute concern for the best interests 
of the patient. The termination of $\mathrm{Dr}$ Von Mollendorff's services is therefore arbitrary and it will contribute to creating an environment where doctors in the public sector feel demoralised and unable to carry out their ethical duties to their patients."

In February 2002, contrary to recommendations in a Department of Health sponsored report, Tshabalala-Msimang said the health ministry would not make a decision on the ARV-program until May 2002.

The Department suddenly settled its case with Von Mollendorff on March 10, 2003 agreeing to compensate him financially and pay his legal fees. This was consequently of the Mpumalanga Department of Health being found out to have squandered R6 million that was supposed to be used for HIV/AIDS services. The Attorney General's report found the department guilty of fraud and corruption, and the Deputy Director General of Mpumalanga advised Manana not to spend money on personal feuds, but rather to focus her attention towards her duties.

\section{Problem statement}

Von Mollendorff was faced with a dual loyalty dilemma - he had to choose between being loyal to his employer, the Department of Health of Mpumalanga, and his obligation as a professional to ensure his patients' best interests, which he thought to be HIV-counseling and ART. He had different alternative actions to choose from, viz. (1) to maintain the status quo, i.e. to disregard his sensed obligation towards his patients and remain loyal to his employer by not allowing GRIP to counsel, debrief and treat the rape victims, or (2) to change the status quo by inviting GRIP into the hospital to counsel and treat rape victims, and at the same time ensuring that his employer was aware of this and approving, or (3) changing the status quo by inviting GRIP into the hospital without ensuring his employer's approval, or (4) taking up the lack of ART and counseling services in the hospital through advocacy and legal groups before changing practices in his hospital, or (5) not allowing the NGO into the hospital but letting his medical officers prescribe ART to the patients who must then buy it themselves, with or without his employer's approval, or (6) only allowing the NGO to counsel the patients and not to treat with ART before the South African 
policy guidelines ensured safety of ART, or (7) allowing another NGO to do only counseling.

At this point in time, antiretroviral treatment was accepted worldwide as a proper prophylaxis to prevent HIV transmission in rape victims. It was however not yet made publicly available in South Africa, and the South African government wanted to be sure that it would be safe in an African population since most of the research on ART was done in the developed world under different population groups. The SA government also did not have the human resources and capacity to activate a proper antiretroviral care program. The National Policy Guidelines did however include treatment of rape victims, and the Victim Empowerment Committee in Nelspruit acted according to this policy when it suggested a care room for rape victims at the hospital. ART in this setting would ensure that an already stigmatised and vulnerable group would not be harmed further by withholding care. Other NGOs were admitted to the Rob Ferreira Hospital complex, and Von Mollendorff made an effort to ensure that the government knew of their plans and endeavours. He tried to arrange a meeting between the superintendents of the regional hospitals with the MEC Manana, and he also wrote a number of letters to the department asking for references on the use of antiretrovirals, especially in vulnerable groups such as rape victims and HIV-infected pregnant women. According to the VEC, he was acting in accordance with the National policy, rather than against it.

On the other hand, one should also take into account that from the government's perspective it would become an extremely unorganised health system if all doctors decided against policies and acted according to their own wills, disregarding guidelines, policies and laws. Many public health programs are protocol-based, and are utterly dependent on the strict adherence to these protocols. The government should however have been more open to communication efforts by Von Mollendorff.

\section{Discussion}

Health professionals are always on the frontline when states fail to adhere to the right of their citizens to the highest attainable standard of health. Sometimes a 
state's failure can cause responsibility conflicts for health professionals. In the case of $\mathrm{dr}$ Von Mollendorff, he thought that adhering to the government's policy of denying medication to uninsured people unjustifiably subordinated his obligation to affirm his patient's right to a high standard of health care. He chose to act in favor of his patient by resisting state restrictions, and subsequently suffered for his actions. The incident did however occur in a political environment amenable to human rights interventions. Many other incidents occur in different environments where the only option remaining for the physician is to adjust his intervention according to the scarce resources or limitations on kinds of care available to the poor.

There may be cases where elevating the state's interests above individual needs, serve social purposes and are accepted as justifiable, e.g. when a client applies for a disability grant, or has a notifiable disease. What is critical about such departures from the accepted primacy of responsibility to the patient, is the fairness and transparency of the balancing of conflicting interests, and the way in which it is consistent with human rights (Physicians for Human Rights 2003). Situations become particularly problematic when responsibility and subsequent loyalty causes acts that support the interest of the state in such a manner that the human rights of the individual are violated. These acts may be influenced by legal requirements, threats of professional or personal harm for non-compliance, the culture of the institution or society where the professional is employed, or even the professional's own sense of duty to the state.

The International Covenant on Economic, Social and Cultural Rights (1966) outlines in Article 12 that "every human being is entitled to the enjoyment of the highest attainable standard of health conducive to living a life in dignity". In 2000, the UN Committee responsible for the interpretation of this Covenant stated that it imposed three types of duties on governments: (1) to respect, requiring states to refrain from interfering directly or indirectly with the enjoyment of the right to the highest attainable standard of health, (2) to protect, requiring states to prevent third parties from interfering in the rights to the highest attainable standard of health, and (3) to fulfill, requiring states to adopt appropriate legislative, administrative, budgetary and other steps toward the full realization of the right to the highest attainable standard 
of health. In the case of Von Mollendorff, obligation (1) and (3) become especially important - the state may not interfere with a citizen's right to health, and appropriate steps should be taken to ensure that marginalized groups attain high standards of care. The state did interfere with the rape victim's care, and did not ensure that the marginalized group of rape victims attain high standards of care.

Denial of the seriousness of the HIV/AIDS pandemic and the lack of political will exacerbates the problem in South Africa (Van Niekerk, 2002). Ex-president Thabo Mbeki's trust in AIDS-denialists, such as so-called scientists Duesburg, Rasnick and Mhlongo, created a huge lag in the progress to develop a sufficient strategy to address the problem. Unfortunately, his handling of the situation increased international prejudice against South Africa and the African continent, leading to HIV/AIDS increasingly being termed "an African epidemic." This ongoing politicisation of the epidemic complicates its management further although its irrelevancy to the apolitical sufferer is clear.

\section{How is this case then relevant to the discussion on responsibility?}

\section{$\underline{\text { Individual responsibility }}$}

Firstly, Thys von Mollendorff may not have ultimate moral responsibility because he is certainly not self-created, but he made a choice and acted upon his choice. His action originated within himself and he was aware of the circumstances surrounding the action. His choice was deliberate - he could influence the outcome of his choice by his actions. The object of his choice was neutral. His choice was attainable by his own efforts. He therefore fulfilled two of the criteria of an Aristotelian theory of moral responsibility, namely deliberate choice, and voluntary action. Praise or blame could then be assigned to his choice and his action.

He was also not objective towards his patients, but subjective, i.e. he had reactive attitudes (Strawson 1962) as part of his human condition. A clear definition of determinism, encompassing the reduction of the reactive attitudes to objective attitudes in every sense of the word, could not be applied to Von Mollendorff's 
attitude towards his patients. His attitudes towards his patients and his colleagues included love, resentment, hurt and forgiveness.

He also incorporated a cognitive element (Wallace 2002) by deliberating about what is best for his patients taking all evidence into account, and not only acting on emotional stimuli. He was able to grasp the moral dilemma surrounding his situation, and to adapt his behaviour according to his own morality, and to that which he believed was in the interest of his patients. It was therefore not unfair to hold Von Mollendorff responsible for his choices and actions, since his powers of reflective self-control were not impaired. The question may then be asked if what Von Mollendorff experienced, was only an example of moral luck (Nagel 2007). However, Von Mollendorff viewed himself not only as a portion of the world, as a necessary link in a chain of events, but he experienced definite boundaries between himself and the world as such. His acts were still his, i.e. he took ownership of his acts, and he was still himself, i.e. he could differentiate between himself and the rest of the world, even if, in theory, an individual's acts and self may be argued out of existence by determinists.

According to Strawson's (2007) basic argument, Von Mollendorff could not have been self-created and therefore he could not have been ultimately morally responsible. He could change his behaviour, but not ever to become ultimately morally responsible. However, even if determinism were true, he felt as if he had a choice, even if this feeling only meant that he was not aware of the probable cause of his action.

Von Mollendorff could also choose between different alternative possibilities (Frankfurt 1969) and act according to his choice. He could have decided to keep the status quo, or to improve the care of patients living with HIV/AIDS. He had a first order desire to do something, i.e. to provide his patients with HIV-counseling and antiretrovirals. His second order desire was to hope that his first order desire, that of giving antiretrovirals and counseling, would be followed through and effective. He was therefore free to act according to Frankfurt's conditions. 
Thys von Mollendorff was reckoned to have a sane deeper self (Wolf 2007); he was able to rationalise his options. He was able to evaluate himself in a sensible and accurate fashion, and he was able to transform his character according to this evaluation. He could be held responsible for the self he was, but not for the self that was created originally by someone or something outside of his self. He could be held responsible for his own deep self, although, if determinism were true, something 'outer-self' would still be responsible for the levels of reflection which extends beyond his deep self. Von Mollendorff was therefore responsible as an individual up to a point, even if not ultimately responsible. This point included his decision to provide his patients with HIV-counseling and antiretroviral medication.

\section{Medical Responsibility}

Von Mollendorff worked as a medical professional in a State hospital. When making decisions in his setting, he had to regard all six levels of moral agency that Pellegrino (1982) described. He was, firstly, involved in healing relationships with his patients and had to consider the mutual obligation that existed between him and his patients. He was also part of a collective decision-making process, being employed in a hospital and working for a government institution. His decisions and actions contributed to the collective decisions and actions of the hospital where he worked. As a medical professional, he was obliged to follow the rules, regulations and ethics of his profession. He was an individual with a well-developed belief and value system, and he had to consider his own morality when making decisions about patients and their families. He also had to take into account his own religious and transcendental ethics, as well as those of his colleagues and patients. All of these levels contributed to his decisions when faced with a medical-moral dilemma, such as described in this case study.

As a medical professional, Von Mollendorff had to give consent to the role he agreed to act within. This consent included three dimensions: (1) He had to accept his role as a medical professional, and had to agree to act as a representative of his profession, (2) He had to enact his role, which depended on the variety of skills and qualities which he possessed, and (3) The morality of the role itself, which was in a 
sense not a role that he agreed with since his employer at the time had, according to Von Mollendorff, refused HIV-patients needed care.

Walsch (1970) argued that such a role does not entertain voluntary action, but as Flores and Johnson (1983) said, Von Mollendorff indeed chose his membership of this role, he certainly gained benefit from it at times, and he could add his own qualities and values to this role. But just because he accepted role responsibility and was therefore part of the medical profession, a collective accepting collective responsibility, did not mean that he was shielded from individual liability or accountability. Even when being part of this collective, he was still autonomous in a sense, he causally contributed to the profession's actions, and he had to fulfill his duty to protect public health. This caused internal conflict because of the different loyalties he had to entertain to different entities, i.e. his patients, the hospital where he worked, the profession itself, and the government whom he worked for.

He therefore acted as an individual, as a doctor bound by the ethics of the profession, and legally bound to the State, his employer. He represented the profession and the State, and was thus responsible as an individual, but also as part of a collective. He still had to accept individual responsibility even while part of a government structure. His profession was regulated by a professional body, but this body could be (and indeed was) acting in direct opposition to the local government. He also had to satisfy general morality.

His patients had a contract with the hospital as an institution, and therefore all staff members were liable and culpable according to their own acts of influence. According to Newton's models (1982), the hospital where they worked would then be reckoned to be an authoritative model, with an internal decision-making structure. It could, however, also be a participatory model, with all the doctors in unison agreeing to treat rape victims with antiretrovirals. Thys von Mollendorff was, however, only responsible for the quality of care of his patients at a very specific point in time and space. He was not able to influence all decisions with regards to his patients, so even in such a complex system of responsibilities, there is a limit to an individual's contribution. 
He was however, faced with an internal conflict situation, where moral responsibility was due to either: his patients or the group served by him; and/or his partners in the decision-making process, i.e. the other hospital staff members and his employer, the provincial department of health; and/or his own moral beliefs and principles. He had to deliberate about his alternative actions, and about the possible consequences of these actions. He had to face praise and blame from an individual, as well from a collective, point of view. As an individual, he was praised by members of the collectives he belonged to, viz. the health professions council and the South African Medical Association, but he was blamed by his employer, the provincial department of health. As a collective, the hospital where he worked was blamed by the department of health for its action, but it was praised by the South African Medical Association and international medical professional associations. His decision to allow antiretroviral therapy for his patients led to an individual sacrifice he lost his position as superintendent, but it sparked an international debate which forced the South African Department of Health to start treating people living with HIV/AIDS with antiretrovirals. Although he was held responsible from an individual and a collective point of view, his sacrifice was purely individual. The collectives which he belonged to, was not harmed in any way.

This leads to the conclusion that an individual may be judged morally responsible on an individual and a collective level, but when blame is apportioned, the allocation of blame may not always seem fair to the individual although the long-term consequence may benefit the collective of which he is a part of.

\section{$\underline{\text { An ethics of responsibility }}$}

An ethics of responsibility emphasizes the choice of an individual's action, where the responsibility for one's choice and the consequence thereof is priority. Thys von Mollendorff was presented with a moral-medical dilemma, a situation of dual loyalty. This situation called for a difficult choice to be made. He deliberated, gathered knowledge and chose according to his preference, a choice which consequences he thought would be best for his patients. He did not follow the rule, tradition, principle or code of his profession and employer blindly. 
He dealt with a changing moral society where human nature and action have changed, and where a new ethics have emerged. This ethics of responsibility takes Nature into account; ethical decisions have become cumulative and are not bound by time and space. Von Mollendorff made a choice of which he was certain the consequences may not be beneficial to his career, but he looked beyond space and time to the long-term effect of his decision to treat patients with antiretrovirals. He could see the cumulative effect of more of his colleagues making the same choice, and the benefit this choice could have on people living with HIV/AIDS in South Africa. Although he could not predict exactly what the consequences of his choice would be, he had the technical knowledge to realise the influence his choice could have on patients' lives. He accepted the call of duty, the responsibility for his choice and was accountable for the consequences that followed. In such a way, he chose to and became responsible for the 'Other', accepting a non-relative moral responsibility on a multi-disciplinary level, regarding different social and cultural values.

Von Mollendorff needed to re-interpret the law. His decision was not completely according to the rule, but also not completely without the rule, which follows Derrida's 'épochè of the rule'. His interpretation of the rule did however, lead to a change in the rule. He appraised the rule before he started to use it, and found it lacking. To him, ethical behaviour was the responsible use of rules.

Van Niekerk (2008) said that an ethics of responsibility means that a decision must be made to move forward. Von Mollendorff made such a decision, and acted upon it. His action was at risk of failure, and in a sense, as an individual, he did fail by losing his position as superintendent. His choice and subsequent action could also have been a wrong choice and a wrong action from someone else's perspective, for instance the Department of Health at the time, but by abiding to an ethics of responsibility this possibility was covered. By accepting responsibility and by being accountable for any possible consequences of his actions, even a wrong action was still a responsible one. 
He did therefore have responsible moral behaviour. He thus used practical wisdom to apply guidelines or codes to the situation at hand through the process of deliberation.

\section{Conclusion}

This case study tried to show the ways in which responsibility could be interpreted in the medical world: firstly, as a moral responsibility on a metaphysical basis where a person is or is not responsible for her actions, according to whether determinism is true. Secondly, as a medical professional who is responsible for her actions as an individual and as part of a collective, and who could be held negligent for not acting accordingly. But such an individual has to fulfill many roles and therefore has many different entities that she is accountable to, which makes decision-making increasingly complex. Thirdly, responsibility in the medical world could be interpreted as an ethics of responsibility, which makes an individual responsible for all his thoughts, choices and actions, and the consequences thereof, and has as a necessary condition the acceptance of all consequences of actions chosen.

And finally - the etymology of the word responsible, is to answer the question "why did you do it?", i.e. to be answerable or accountable for one's actions (Lucas 1993). Responsibility thus means to answer the question, in Greek logon. The question in every health care worker's mind today in the South African context should be "Why am I not treating this HIV positive child or adult with ART?" The responsibility of every role player in the healthcare system, as individual and/or team member, should therefore be amongst others, to ensure that all HIV-positive individuals have access to treatment and are treated fairly, effectively and without delay. 


\section{Concluding Remarks}

This thesis primarily aimed to discuss questions surrounding the notion and practice of responsibility in the health care setting against the background of an HIV/AIDS epidemic in South Africa. The term responsibility was interpreted and discussed in different ways, viz. the history and meaning of individual responsibility, medical responsibility in an individual and a collective sense, and an ethics of responsibility. These interpretations were then applied to the case study of dr Thys von Mollendorff. By using this case study, the author hoped to highlight the plight of medical professionals dealing with HIV/AIDS in South Africa, where the proper assignment of responsibility is of cardinal importance to ensure good quality of care for people living with HIV/AIDS.

Because of the fact that South Africa faces a major AIDS epidemic, the Department of Health needs to focus on the improvement of health and well-being of people living with HIV/AIDS. These people are almost exclusively poor, vulnerable and not well educated. Not only does anti-retroviral therapy need to be available to all people infected with HIV who meet the criteria for treatment, but the social upliftment and improvement of education should also form part of the responsiblity of the government to ensure that this vulnerable group infected with HIV and affected by the epidemic, is taken care of.

When the question is asked of who is to take responsibility for people living with HIV/AIDS, this thesis poses an answer. Not only is the patient as an individual responsible for her own health, but so is her primary care giver: the nurse, doctor or community health worker that looks after her well-being. Not only is the primary care giver responsible as an individual medical professional, but he is also part of several medical collectives, which could include an emergency response team, a hospital or a practice. Not only the person infected with HIV is affected by the epidemic, but so is society at large which therefore should abide by an ethics of responsibility. Each individual person who forms part of the South African society should thus realise that we have an obligation to accept our moral responsibility and 
in doing so, discover the truth. We should also realise that responsibility deals with different kinds of ethical approaches and moves beyond the realm of relativity; that it is multi-disciplinary and that it includes not only technical and economical values, but also environmental, social and cultural values.

This thesis thus dealt with the question of responsibility in the health care setting in South Africa. By elaborating on different aspects or meanings of responsibility, the author tried to answer the following questions: "Can any individual have ultimate moral responsibility? What is a medical professional's individual or collective responsibility? What is an ethics of responsibility with regards to the health care setting?" These questions were discussed on a philosophical basis, but then elaborated upon while taking the high HIV/AIDS prevalence in South Africa into account, and the day-to-day application of such concepts of responsibility when a complex bio-psycho-social disease such as HIV/AIDS is confronted with.

The different concepts of responsibility in the health care setting, with specific regards to people living with HIV/AIDS in South Africa, were highlighted and illuminated by means of a case discussion. The author discussed three different concepts of responsibility, taking into account that other concepts may exist, but focusing on these because of their direct importance to the health care setting and medical professionalism in South Africa. It is however important to realise that the different concepts of responsibility each contributed to the question of who is responsible for health care in South Africa, and with regards to this thesis, who is responsible for caring for people living with HIV/AIDS in South Africa.

Firstly, the concept of an individual's moral responsibility per se is directly of consequence when responsibility needs to be ascribed to any individual living in South Africa and dealing on a daily basis with HIV/AIDS, whether it is as a patient, a medical professional, a government official, or any bystander witnessing the advance of the disease.

Secondly, all medical professionals in South Africa are responsible as individuals, and their choices and actions are therefore attributable to them. They are however, not only responsible as individuals, but also as professionals. As professionals, they have 
further duties and obligations which conform to the role of the professional and which they are obliged to adhere to. These duties include a certain way of decisionmaking and a certain way of action, which is not part of the responsibility ascribed to the man in the street. Medical professionals are responsible in their individual capacity, but as the thesis showed, they are also responsible as part of different collectives.

Thirdly, any individual could choose to adhere to an ethics of responsibility. Such an individual would then at all times take into account not only his choices made and actions taken, but also the consequences of his actions ad infinitum, or at least the ones he would realistically know of. Any individual working with people living with HIV/AIDS in South Africa could, and should make the choice of adhering to an ethics of responsibility.

Hopefully the discussion contributed to the assignment of responsibility to all parties involved in the HIV/AIDS epidemic in South Africa. It is hoped that by illuminating the different aspects of responsibility in health care in South Africa, the involved parties would come to the realisation that each and all are responsible for the improvement of the well-being of our fellow South Africans living with HIV/AIDS. The work documented here may contribute to a paradigm shift with regards to taking responsibility for people living with HIV/AIDS, which could influence the urgency of government action to ensure all such individuals have access to HIV care. This in turn may lead to a more positive international attitude towards the South African Department of Health and other role players involved, especially since South Africa has been severely criticised with regards to the management of the epidemic. 


\section{Bibliography}

Altenroxel, L. (2002, March 1). Doctor on the carpet for sticking to oath. Retrieved May 2, 2007, from The Star: http://www.grip.org.za/news/doctor.htm

American Psychological Association. (2002). Ethical principles of psychologists and codes of conduct. American Psychologist , 57 (12), 1060-1073.

Amnesty International. (2003). Annual Report January - December 2002. Retrieved May 2, 2007, from http://web.amnesty.org/report2003/Zaf-summary-eng

Anscombe, E. (1958). Modern Moral Philosophy. Philosophy, 33 (124).

Aristotle. (1955). The Ethics of Aristotle (2nd ed.). (E. V. Rieu, Ed., \& J. A. Thomson, Trans.) London: The Whitefriars Press Ltd.

Ayer, A. J. (2007). Freedom and Necessity. In R. Shafer-Landau (Ed.), Ethical Theory: An Anthology (pp. 349-354). Blackwell Publishing.

Baier, K. (1991). Guilt and Responsibility. In L. May, \& S. Hoffman, Collective Responsibility: Five Decades of Debate in Theoretical and Applied Ethics (pp. 197218). Rowman \& Littlefield.

Baleta, A. (2002). South African doctor sacked for giving antiretrovirals to rape survivors. The Lancet, 359, 954.

Bates, S. (1971). The Responsibility of "Random Collections". Ethics, 81 (4), 343-349.

Bauman, Z. (1992). Intimations of Postmodernity. London and New York: Routledge.

Bauman, Z. (1995). Life in Fragments. Oxford: Blackwell Publishers.

Bauman, Z. (1993). Postmodern Ethics. Oxford: Blackwell Publishers.

Beauchamp, T. L., \& Childress, J. F. (1994). Principles of biomedical ethics (4th ed.). New York: Oxford University Press.

Bok, H. (1998). Freedom and Responsibility. Princeton University Press. 
Bowie, N. E. (1982). 'Role' as a Moral Concept in Health Care. The Journal of Medicine and Philosophy, 7, 57-63.

Cilliers, P. (1998). Complexity and Postmodernism: Understanding Complex Systems. London and New York: Routledge.

Cooper, D. (1968). Collective Responsibility. Philosophy, 43 (165), 258-268.

Cooper, D. E. (1969). Collective Responsibility: Again. Philosophy , 44 (168), 153-155.

Corlett, J. A. (2001). Collective Moral Responsibility. Journal of Social Philosophy, 32 (4), 573-584.

Coulehan, J., Williams, P. C., Van McGrary, S., \& Belling, C. (2003). The Best Lack All Conviction: Biomedical Ethics, Professionalism and Social Responsibility. Cambridge Quarterly of Healthcare Ethics, 12, 21-38.

Crawford, N. C. (1998). Postmodern Ethical Conditions and a Critical Response. Ethics and International Affairs, 12 (1), 121-140.

De George, R. T. (1982). The Moral Responsibility of the Hospital. The Journal of Medicine and Philosophy, 7, 87-100.

Derrida, J. (1992). Force of Law: The "Mystical Foundation of Authority". In D. Cornell, M. Rosenfeld, \& D. G. Carlson (Eds.), Deconstruction and the Possibility of Justice (pp. 3-67). London and New York: Routledge, Chapman and Hall, Inc.

Derrida, J. (1995). The Gift of Death. (D. Wills, Trans.) Chicago: University of Chicago Press.

Downie, R. (1969). Collective Responsibility. Philosophy , 44 (167), 66-69.

Downie, R. S. (1982). Collective Responsibility in Health Care. The Journal of Medicine and Philosophy, 7, 43-56.

Eshleman, A. (2004, Aug 14). Moral Responsibility. Retrieved Jan 11, 2008, from Stanford Encyclopedia of Philosophy: http://plato.stanford.edu/entries/moralresponsibility/

Feinberg, J. (1968). Collective Responsibility. The Journal of Philosophy , 65 (21), 674688. 
Fired AIDS doctor to take case to labour court. (2002, July 22). Retrieved May 2, 2007, from SABC News: http://www.sabcnews.co.za/Article/PrintWholeStory/0,2160,39151,00.htm

Fired Hospital Head Loses Appeal. (2002, May 17). Retrieved May 2, 2007, from Dispatch: http://www.dispatch.co.za/2002/05/18/southafrica/APPEAL.htm

Fischer, J. M. (1999). Recent Work on Moral Responsibility. Ethics, 110, 93-139.

Fischer, J. M., \& Ravizza, M. (1998). Responsibility and Control. New York: Cambridge University Press.

Flores, A., \& Johnson, D. G. (1983). Collective Responsibility and Professional Roles. Ethics, 93 (3), 537-545.

Frankfurt, H. G. (1969). Alternate Possibilities and Moral Responsibility. The Journal of Philosophy , 66 (23), 829-839.

Frankfurt, H. G. (1971). Freedom of the Will and the Concept of a Person. The Journal of Philosophy , 68 (1), 5-20.

French, P. A. (1982). Collective Responsibility and the Practice of Medicine. The Journal of Medicine and Philosophy, 7, 65-85.

French, P. (1979). The Corporation as a Moral Person. American Philosophical Quarterly, 16 (3), 297-317.

Gauthier, C. C. (2005). The Virtue of Moral Responsibility and the Obligations of Patients. Journal of Medicine and Philosophy, 30, 153-166.

Gibson, K. (1995). Fictitious persons and real responsibilities. Journal of Business Ethics , 14 (9), 761-767.

Gomperz, H. (1939). Individual, Collective and Social Responsibility. Ethics, 49 (3), 329-342.

Goodpaster, K. (1983). The concept of corporate responsibility. Journal of Business Ethics , 2 (1), 1-22. 
Held, V. (1970). Can a Random Collection of Individuals be Morally Responsible? The Journal of Philosophy, 67 (14), 471-481.

Hobbes, T. (2008). Leviathan. Forgotten Books.

Human Rights Watch. (2004). Deadly Delay: South Africa's Efforts to Prevent HIV in Survivors of Sexual Violence. Retrieved May 2, 2007, from http://hrw.org/reports/2004/southafrica0304/4.htm

Huprich, S. K., Fuller, K. M., \& Schneider, R. B. (2003). Divergent Ethical Perspectives on the Duty-to-Warn Principle with HIV Patients. Ethics \& Behavior , 13 (3), 263-278.

Jonas, H. (1984). The imperative of responsibility: in search of an ethics for the technological age. Chicago: University of Chicago Press.

Ladd, J. (1991). Bhopal: An Essay on Moral Responsibility and Civic Virtue. Journal of Social Philosophy, 32 (1), 73-91.

Landman, W. (2002). Respect doctors' ethical obligations. Indian Journal of Medical Ethics, 10 (2).

Lewis, H. (1948). Collective Responsibility. Philosophy, 23 (84), 3-18.

Locke, J. (1841). An Essay concerning Human Understanding. Oxford: Thomas Tegg.

London, L. (2005). Dual Loyalties and the Ethical and Human Rights Obligations of Occupational Health Professionals. American Journal of Industrial Medicine , 47, 322332.

Lucas, J. R. (1993). Responsibility. Oxford: Clarendon Press.

Maclntyre, A. C. (1984). After virtue: A study in Moral Theory (2nd ed.). Notre Dame (IN): University of Notre Dame Press.

Mason, E. (2005). Moral Responsibility. Philosophical Books , 46 (4), 343-353.

May, L., \& Hoffman, S. (1991). Collective Responsibility: Five Decades of Debate in Theoretical and Applied Ethics. Rowman \& Littlefield.

McGary, H. (1986). Morality and Collective Liability. The Journal of Value Inquiry, 20, 157-165. 
McLean, G. R., \& Jenkins, T. (2003). The Steve Biko Affair: A Case Study in Medical Ethics. Developing World Bioethics , 3 (1), 77-95.

Mollendorff, T. v. (2009). Daring to care. In K. Cullina, \& A. Thom, The Virus, Vitamins and Vegetables (pp. 77-90). Auckland Park: Jacana.

Murphy, C. (1978). The moral situation in nursing. In E. L. Bandman, \& B. Bandman (Eds.), Bioethics and Human rights (pp. 313-320). Boston, Massachusetts, USA: Little, Brown and Company.

Nagel, T. (2007). Moral Luck. In R. Shafer-Landau (Ed.), Ethical Theory: An Anthology (pp. 355-362). Blackwell Publishing.

Narveson, J. (2002). Collective responsibility. The Journal of Ethics , 6, 179-198.

Newton, L. (1982). Collective Responsibility in Health Care. The Journal of Medicine and Philosophy, 7, 11-21.

Nietzsche, F. W. (1973). Beyond good and evil: prelude to a philosophy of the future. (R. J. Hollingdale, Trans.) London: Penquin.

Ozar, D. T. (1982). Three Models of Group Choice. The Journal of Medicine and Philosophy, 7, 23-34.

Paton, H., \& Kant, I. (1991). The Moral Law: Kant's 'Groundwork of the Metaphysic of Morals'. (H. Paton, Trans.) Routledge.

Pellegrino, E. D. (2002). Professionalism, Profession and the Virtues of the Good Physician. The Mount Sinai Journal of Medicine , 69 (6), 378-384.

Pellegrino, E. D. (1982). The Ethics of Collective Judgments in Medicine and Health Care. The Journal of Medicine and Philosophy, 7, 3-10.

Pellegrino, E. D., \& Relman, A. S. (1999). Professional Medical Associations: Ethical and Practical Guidelines. JAMA , 282 (10), 984-986.

Physicians for Human Rights. (2003). Dual Loyalty \& Human Rights in Health Professional Practice; Proposed Guidelines and Institutional Mechanisms. Retrieved May 2, 2007, from http://physiciansforhumanrights.org/library/2003-03-06.html 
Rachels, J. (2003). The Elements of Moral Philosophy (4th ed.). New York: McGrawHill.

Ranken, N. (1987). Corporations as persons: Objections to Goodpaster's 'principle of moral projection'. Journal of Business Ethics , 6 (8), 633-637.

Rawls, J. (1971). A Theory of Justice. Oxford: Oxford University Press.

Rawls, J. (2001). A Theory of Justice. In K. Schaff (Ed.), Philosophy and the Problems of Work: A Reader (pp. 179-200). New York: Rowman \& Littlefield.

Reinstate axed hospital head: Wits experts. (2002, March 7). Retrieved May 2, 2007, from SAPA: www.q.co.za/2001/2002/03/07-aids.html

Resource Allocation in Health Care. (2006). Retrieved June 25, 2007, from UK Clinical Ethics Network: http://www.ethics-network.org.uk/Ethics/eresource.htm

Shafer-Landau, R. (2007). Ethical Theory: An Anthology. Blackwell Publishing.

Smiley, M. (2005, August 8). Collective Responsibility. Retrieved August 21, 2008, from Stanford Encyclopaedia of Philosophy: http://plato.stanford.edu/entries/collective-responsibility/

Solomon, M. Z. (2005). Healthcare Professional and Dual Loyalty: Technical proficiency is not enough. Medscape General Medicine , 7 (3), 14.

Strawson, G. (2007). The Impossibility of Moral Responsibility. In R. Shafer-Landau (Ed.), Ethical Theory: An Anthology (pp. 344-348). Blackwell Publishing.

Strawson, P. (1962). Freedom and Resentment. Proceedings of the Britich Academy, $48,181-211$.

Taylor, R. (2007). Determinism and the Theory of Agency. In R. Shafer-Landau (Ed.), Ethical Theory: An Anthology (pp. 340-343). Blackwell Publishing.

The International Covenant on Economic, Social and Cultural Rights. (1966). Retrieved from http://www.unhchr.ch/html/menu3/b/a_cescr.htm

The South African Medical Association's work on the HIV/AIDS front. (2004). World Medical Journal , 50 (1), 26-27. 
Treatment Action Campaign. (2002, March 18). Statement by academics on sacking of $d r$ Thys von Mollendorff. Retrieved January 30, 2007, from TAC Newsletter: http://www.tac.org.za/newsletter/2002/ns18_08_2002.txt

Truth and Reconciliation Report. (1998). Truth and Reconciliation Commission of South Africa Report. Retrieved June 17, 2007, from http://www.doj.gov.za/trc/report/finalreport/TRC\%20VOLUME\%204.pdf

Van Niekerk, A. A. (2008). An Ethics of Responsibility. 14th World Congress of Anesthesiologists, (pp. 1-7). Cape Town.

Van Niekerk, A. A. (2002). Moral and Social Complexities of AIDS in Africa. Journal of Medicine and Philosophy, 27 (2), 143-162.

Van Niekerk, A. A. (2005). Principles of Global Distributive Justice and the HIV/AIDS Pandemic. In A. A. Van Niekerk, \& L. M. Kopelman (Eds.), Ethics \& AIDS in Africa: The Challenge to our Thinking (pp. 84-110). Claremont, South Africa: David Philip Publishers.

Vargas, M. (2005). The Revisionist's Guide to Responsibility. Philosophical Studies, 125, 399-429.

Velasquez, M. (1983). Why Corporations are not Morally Responsible for what they do. Business and Professional Ethics Journal , 2, 1-18.

Wallace, R. J. (2002). Precis of Responsibility and the Moral Sentiments. Philosophy and Phenomenological Research , 64 (3), 680-681.

Walsh, W. (1970). Pride, Shame and Responsibility. Philosophical Quarterly, 20, 1-13.

Whiteside, A., \& Sunter, C. (2000). AIDS: The Challenge for South Africa. Cape Town: Human \& Rousseau.

Wilmot, S. (2000). Corporate Moral Responsibility in Health Care. Medicine, Health Care and Philosophy , 3, 139-146.

Wolf, S. (2007). Sanity and the Metaphysics of Responsibility. In R. Shafer-Landau (Ed.), Ethical Theory: An Anthology (pp. 363-373). Blackwell Publishing.

World Medical Association. (2005). Medical Ethics Manual. Retrieved June 10, 2007, from http://www.wma.net/e/ethicsunit/pdf/manual/intro.pdf 